\title{
Distribution of barium in the Weddell Gyre: Impact of circulation and biogeochemical processes
}

\author{
M. Hoppema ${ }^{\text {a,* }}$, F. Dehairs ${ }^{\text {b }}$, J. Navez ${ }^{\text {b,c }}$, C. Monnin ${ }^{\text {d }}$, C. Jeandel ${ }^{\text {e }}$, E. Fahrbach ${ }^{\text {a }}$, H.J.W. de Baar ${ }^{\mathrm{f}}$ \\ a Alfred Wegener Institute for Polar and Marine Research, Climate Sciences Department, Postfach 120161, D-27515 Bremerhaven, Germany \\ ${ }^{\mathrm{b}}$ Vrije Universiteit Brussel, Earth System Sciences \& Analytical and Environmental Chemistry, Pleinlaan 2, B-1050 Brussels, Belgium \\ c Royal Museum for Central Africa, Geology and Mineralogy, Section of Mineralogy and Petrography, Leuvensesteenweg, B-3080 Tervuren, Belgium \\ d Laboratoire Mécanismes de Transfert en Géologie, CNRS/Université Paul Sabatier, 16 Avenue Edouard Belin, F-31400 Toulouse, France \\ e Laboratoire d'Etudes en Géophysique et Océanographie Spatiales (LEGOS), Observatoire Midi Pyrénées, F-31400 Toulouse, France \\ ${ }^{\mathrm{f}}$ Royal Netherlands Institute for Sea Research, Postbus 59, NL-1790 AB Texel, The Netherlands
}

\section{A R T I C L E I N F O}

\section{Article history:}

Received 5 February 2010

Received in revised form 2 July 2010

Accepted 15 July 2010

Available online 22 July 2010

\section{Keywords:}

Barium

Silicate

Geochemical cycle

Southern Ocean, Weddell Sea

\begin{abstract}
A B S T R A C T
The Southern Ocean data base of dissolved barium $\left(\mathrm{Ba}_{\mathrm{d}}\right)$ has been augmented with two densely sampled sections across the Weddell Gyre sampled by the icebreaker FS Polarstern during February and March 2005. $\mathrm{Ba}_{\mathrm{d}}$ was found to be relatively high in the surface layer as compared to the adjacent waters north (Antarctic Circumpolar Current) and east (Antarctic Zone of the Indian sector). Compared to the inflowing water into the Weddell Gyre and also to the surface water, the deep water is characterized by a significant $\mathrm{Ba}_{\mathrm{d}}$ enrichment. Depletion of $\mathrm{Ba}_{\mathrm{d}}$ in the surface layer is associated with well-known biogeochemical processes, but we speculate that also sea-ice formation leads to the extraction of Ba from solution via barite $\left(\mathrm{BaSO}_{4}\right)$ precipitation. The particulate Ba settles down the water column and redissolves in deeper water where undersaturation of barite is prevalent. In the bottom layer, enrichment of $\mathrm{Ba}_{\mathrm{d}}$ occurs, exhibited as a $\mathrm{Ba}_{\mathrm{d}}$ maximum, which is caused by Ba efflux from the sediments. In recently formed Weddell Sea Bottom Water, though, a $\mathrm{Ba}_{\mathrm{d}}$ minimum is observed, imposed by the shelf water component of bottom water, which has relatively low $\mathrm{Ba}_{\mathrm{d}}$ concentration. Like in other Southern Ocean regions, throughout the water column a strong correlation exists between $\mathrm{Ba}_{\mathrm{d}}$ and dissolved silicate, although the relationship is different from that in the Antarctic regions to the east. In a tentative budget, the deep water is found to be supplied with $\mathrm{Ba}_{\mathrm{d}}$ mainly by the surface layer, but also to some extent by the bottom layer. Weddell Sea Deep Water, enriched in $\mathrm{Ba}_{\mathrm{d}}$, is transferred out of the Weddell Gyre into the ACC as Antarctic Bottom Water, making the gyre a source of $\mathrm{Ba}_{\mathrm{d}}$ to the deep and abyssal world oceans.
\end{abstract}

(C) 2010 Elsevier B.V. All rights reserved.

\section{Introduction}

Like other chemical species, the distribution of barium $(\mathrm{Ba})$ in the oceans is controlled by water circulation. Consequently, barium has been utilized as a water mass tracer (e.g., Chan et al., 1977; Falkner et al., 1994). However, many studies have found that there is nonconservative behavior of Ba as well, namely, due to biologically associated uptake followed by dissolution (Chan et al., 1977; Jeandel et al. 1996). These conditions impose that Ba be categorized as a biointermediate element. Higher biomass and productivity in the upper mixed layer usually coincide with higher Ba concentrations in suspended matter (e.g., Cardinal et al., 2005; Jacquet et al., 2007a). Most of this upper mixed layer particulate, non-lithogenic Ba consists of Ba absorbed by or adsorbed on planktonic material (Cardinal et al., 2005; Collier and Edmond, 1984; Jacquet et al. 2007b, 2008), though

\footnotetext{
* Corresponding author. Tel.: +49471 48311884.

E-mail addresses: Mario.Hoppema@awi.de (M. Hoppema), fdehairs@vub.ac.be (F. Dehairs).
}

the presence of the mineral barium sulfate has been also demonstrated in living marine phytoplankton (Fresnel et al., 1979; Gayral and Fresnel, 1979) and in freshwater and marine benthic microbial organisms (e.g., Bertram and Cowen, 1997; Hopwood et al., 1997). Also, celestite $\left(\mathrm{SrSO}_{4}\right)$ of acantharians appears to be significantly enriched in barium as compared to the surrounding seawater (Bernstein et al., 1998); these pelagic protozoans constitute a significant part of plankton in the Southern Ocean.

Underneath the surface mixed layer, it is well established that barite is the major carrier of Ba in suspended matter (Dehairs et al., 1980; Jacquet et al., 2007b; Stroobants et al., 1991), although the deeper parts of the ocean are generally undersaturated with respect to this mineral (Monnin et al., 1999; Rushdi et al., 2000). Barite formation occurs essentially in the mesopelagic zone (100-1000 m) within aggregates of decomposing organic detritus (Cardinal et al., 2005; Dehairs et al., 1980, 1990; Stroobants et al., 1991; van Beek et al., 2009). Experimental work by Ganeshram et al. (2003) showed that barite crystals form during the degradation of phytoplankton material. Mesopelagic particulate Ba-barite was observed to be 
correlated with the rate of oxygen consumption (Dehairs et al., 1997) and subsurface bacterial activity (Dehairs et al., 2008; Jacquet et al., 2008).

Because of the link of barium and barite to ocean biological productivity, and the fact that barite is well preserved in sediments due to its low solubility, barium and barite have been used as a paleoproxy, i.e., a paleo recorder of export production (e.g., Dymond et al., 1992; Paytan and Griffith, 2007). Since dissolved Ba in the oceans is the main constraint for the chemistry of barite, it is essential that the large-scale Ba distribution and the barium cycle in the world oceans be known. The present study explores the distribution of dissolved $\mathrm{Ba}$ (and for comparison that of silicate) in the water column of the Weddell Gyre, an area for which there is a dearth of data on Ba, despite its importance in terms of formation of ventilated deep and bottom water, upwelling and sea-ice formation. Earlier data for the Weddell region were obtained during the GEOSECS project, but they consist of just a few full-depth profiles, plus some surface and bottom water data (Chan et al., 1977; Östlund et al., 1987). Expedition ANTXXII/3 in 2005 offered the possibility to investigate Ba along the Prime Meridian and at a section across the Weddell basin (Fig. 1), thereby significantly expanding the Southern Ocean data set, which thus far consists of sections along $30^{\circ} \mathrm{E}$ (WOCE I6; unpublished results of Dehairs et al.), $145^{\circ} \mathrm{E}$ (WOCE SR3; Jacquet et al., 2004), a section in the Crozet-Kerguelen Basin (Jacquet et al., 2005) and a series of profiles in the Indian sector (INDIGO 1 and 3; Jeandel et al., 1996).

\section{Material and methods}

Data were collected (Fig. 1) during FS Polarstern cruise ANT-XXII/3 from Cape Town, South Africa to Punta Arenas, Chile, 22 January to 6 April 2005 (Fahrbach, 2006). Water was sampled with the rosette sampler coupled to the CTD instrument (conductivity temperature depth; SBE911plus) throughout the water column, with a bias to the upper $1000 \mathrm{~m}$. Temperature and salinity were measured with a precision of $0.001{ }^{\circ} \mathrm{C}$ and 0.002 , respectively (Fahrbach, 2006).

\subsection{Dissolved barium}

Volumes of $15 \mathrm{ml}$ of unfiltered seawater were sampled in polypropylene vials (Nalgene), which were rinsed three times with the sample seawater. Samples were acidified with $15 \mu \mathrm{HCl}$ (Merck Suprapur) and stored at room temperature until analysis in the home laboratory. No filtration of the seawater was attempted based on the well documented knowledge that dissolved Ba represents, in general, a very large fraction (>99\%) of total Ba. In productive surface mixed

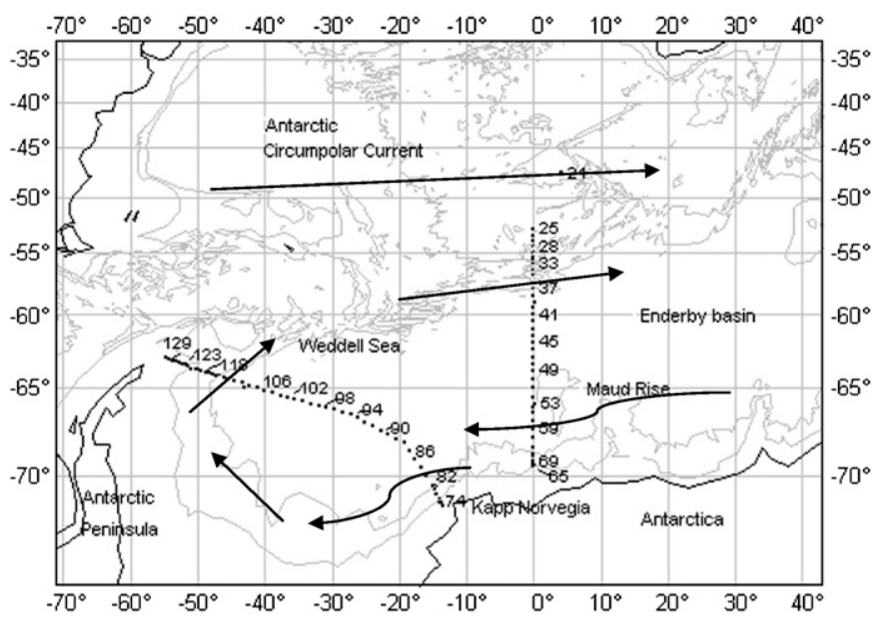

Source: GEBCO.

Fig. 1. Map of the Weddell Sea and environs with station locations during cruise ANT-XXII/3. Arrows denote the schematic surface circulation in the region. layers this may be different, but also here particulate Ba is usually $<3 \%$ of total Ba (e.g., see Jacquet et al., 2007a; 2008). Dissolved Ba was measured using an isotope dilution method described below; in fact, the dissolved Ba measurements presented here represent soluble Ba, consisting of dissolved Ba plus a very small fraction (generally $<1 \%$ of total $\mathrm{Ba}$ ) that is generated from the particulate Ba pool as a result of the acidification. For the sake of simplicity, we prefer to use the term dissolved $\mathrm{Ba}\left(\mathrm{Ba}_{\mathrm{d}}\right)$ in this paper. Sample preparation is as follows: $1 \mathrm{~g}$ of seawater is spiked with $0.7 \mathrm{~g}$ of ${ }^{135} \mathrm{Ba}$-spike solution, yielding a ${ }^{138} \mathrm{Ba} /{ }^{135} \mathrm{Ba}$ ratio between 0.7 and 1 to minimize propagated error (Klinkenberg et al., 1996; Webster, 1960). Subsequently, the sample is diluted with acidified (nitric acid) Milli-Q grade water to a final weight of $30 \mathrm{~g}$. Blanks consist of acidified (with nitric acid) Milli-Q water. Quantities of sample, spike and dilution water were accurately assessed by weighing. Isotope ratios were measured with sector-field inductively-coupled plasma mass spectrometry (SF-ICP-MS; Element 2 Thermo Finnigan). Reproducibility of our method is $\pm 1.5 \%$ (RSD) as tested on repeat preparations of reference solutions. Average Ba values obtained for reference waters SLRS-3 and an in-house standard (a Mediterranean Sea standard prepared by C. Jeandel) were $13.48 \pm$ $0.21 \mu \mathrm{g} \mathrm{l}^{-1}(1 \sigma)$ with RSD of $1.55 \%$ and $10.49 \pm 0.29 \mu \mathrm{g} \mathrm{l} \mathrm{l}^{-1}(1 \sigma)$ with RSD of $2.75 \%$, respectively, which is in good agreement with the certified values (SLRS-3: $13.4 \pm 0.6 \mu \mathrm{g} \mathrm{l}^{-1}$ and OMP: $10.4 \pm 0.2 \mu \mathrm{g} \mathrm{l}^{-1}$ ). Overall precision (including sampling precision) based on 6 dissolved Ba profiles sampled in a hydrographically stable environment is $\pm 0.3 \mu \mathrm{g} \mathrm{l} \mathrm{l}^{-1}(1 \sigma)$, with an RSD of $5 \%$ (Dehairs et al., 2008; Jacquet, 2007); for further details we refer to the latter two studies. $\mathrm{Ba}_{\mathrm{d}}$ concentrations are expressed in $\mathrm{nmol} \mathrm{kg} \mathrm{kg}^{-1}$.

\subsection{Silicate}

Nutrients were measured on board with a Technicon TRAACS 800 rapid flow autoanalyzer (see also Fahrbach, 2006) by the Royal Netherlands Institute for Sea Research (NIOZ, Texel). Accuracy was determined using stock standards diluted in low-nutrient sea water, as prepared in the home lab by weighing. The precision for silicate was estimated to be $0.66 \mu \mathrm{mol} \mathrm{l}^{-1}$ at two calibration stations, where all 24 rosette bottles were fired at the same depth. Part of the surface layer nutrient data of this cruise have also been reported by Hoppema et al. (2007). Silicate (or silicic acid) concentrations are expressed in $\mu \mathrm{mol} \mathrm{kg}^{-1}$.

\section{3. $\mathrm{BaSO}_{4}$ saturation index calculation}

The barite saturation index (SI) is defined as the ratio of the ionic product of barium sulfate $(\mathrm{Q})$ to the solubility product of barite $\left(K_{\mathrm{sp}}\right)$ :

$S I=\frac{Q}{K_{\mathrm{sp}}}=\frac{m_{\mathrm{Ba}(\mathrm{aq})} \cdot m_{\mathrm{SO}_{4}(\mathrm{aq})} \cdot \gamma_{\mathrm{BaSO}_{4}(\mathrm{aq})}^{2}}{K_{\mathrm{sp}}}$

in which $\mathrm{m}$ is the measured concentration (molality) and $\gamma$ the activity coefficient of aqueous barium sulfate. Monnin (1999) has developed a model of the $\mathrm{Na}-\mathrm{K}-\mathrm{Ca}-\mathrm{Mg}-\mathrm{Sr}-\mathrm{Ba}-\mathrm{Cl}-\mathrm{SO}_{4}-\mathrm{H}_{2} \mathrm{O}$ system that allows the calculation of the solubility and saturation indices of some minerals, including barite, as a function of the solution composition, temperature (up to $200^{\circ} \mathrm{C}$ ) and pressure (up to $1 \mathrm{kbar}$ ). It has been used to investigate the saturation state of the ocean with respect to pure barite (Monnin et al., 1999) and Sr-substituted barites (Monnin and Cividini, 2006). Alternative models restricted to the case of seawater, such as the one proposed by Rushdi et al. (2000), have been shown to give similar results when applied to the GEOSECS Ba data. The criterion for equilibrium retained in these studies is a saturation index between 0.9 and 1.1, which has been inferred from an evaluation of the mean accuracy of the solubility calculations during model development (Monnin, 1999). The measured quantities 
used are dissolved barium molarity, salinity, pressure and potential temperature. The concentrations of $\mathrm{K}, \mathrm{Ca}, \mathrm{Mg}, \mathrm{Ba}, \mathrm{Sr}, \mathrm{SO}_{4}$ and $\mathrm{Cl}$ are calculated from the measured salinity and the composition of standard seawater of salinity 35 using:

$$
c_{i}(S)=c_{i}(35) \times \frac{S}{35}
$$

with $c_{i}(S)$ the concentration (molarity) of the $i$ th element for the sample with salinity $S$. The Na concentration is calculated from the electroneutrality condition. Molarities are converted to molalities using the VOlumetric_PrOperties (VOPO) code (Monnin, 1994). The thermodynamic model then calculates the stoichiometric BaSO4(aq) activity coefficient, the barite solubility product and the barite saturation index at the given temperature and pressure.

\section{Hydrographic background}

The region of investigation is situated in the Antarctic Zone, i.e., south of the Polar Front. The boundary between the Antarctic Circumpolar Current (ACC) and the Weddell Gyre is found at about $56^{\circ} \mathrm{S}$ on the Prime Meridian (Klatt et al., 2005). Thus the majority of data stem from the Weddell region. North of $56^{\circ} \mathrm{S}$, the potential temperature maximum of the Upper Circumpolar Deep Water (UCDW) can be distinguished, centered at 500-600 m (Fig. 2). Circumpolar Deep Water (CDW), characterized by a maximum in the potential temperature $(\theta)$, is transferred into the Weddell Gyre near its eastern end. We observed the temperature maximum at 64$69^{\circ} \mathrm{S}$ at $150-400 \mathrm{~m}$ depth reaching $0.8-1{ }^{\circ} \mathrm{C}$ (Fig. 2); this coincides essentially with the westward flowing southern limb of the Weddell Gyre. Note that the $\theta$ maximum layer is interrupted near $66^{\circ} \mathrm{S}$ by a lower $\theta$ maximum around the undersea mountain Maud Rise. At the northern part $\left(56-63.5^{\circ} \mathrm{S}\right.$ ) of the Prime Meridian section, constituting the northern limb of the gyre with generally eastward flow, a $\theta$ maximum was observed as well, but it reaches only about $0.5^{\circ} \mathrm{C}$ (Fig. 2). This is CDW that has been modified by mixing with waters above and below during its course through the Weddell Gyre. The $\theta$ maximum layer is separated from the base of the surface layer (identified by a temperature minimum) by a sharp pycnocline. In the upper part of the surface layer, temperatures were often $>1.0^{\circ} \mathrm{C}$, but in the coastal region it was significantly colder. These are summer temperatures; in winter the entire surface layer is at, or close to, the freezing point of about $-1.85^{\circ} \mathrm{C}$. Note that the surface layer is deeper in the coastal zone than elsewhere in the basin. The Weddell Gyre is a divergent feature with upwelling of deep water, mainly more or less modified CDW; the surface layer is eventually generated from this upwelled water. In the deep Weddell basin, $\theta$ decreases monotonically from the $\theta$ maximum to a minimum at the sea floor. Weddell Sea Bottom Water (WSBW) is present along the section, being defined by $\theta<-0.7^{\circ} \mathrm{C}$. Between the lower boundary of the $\mathrm{CDW}$ at $0{ }^{\circ} \mathrm{C}$ and the WSBW, the most voluminous water mass of the Weddell Gyre is found, the Weddell Sea Deep Water (WSDW). It is replenished by upward mixing of WSBW with CDW, by local water mass formation processes (Orsi et al., 1993), but also by advective transport from the east (Meredith et al. 2000; Hoppema et al., 2001). In the deep Weddell basin, $\theta$ decreases monotonically from the $\theta$ maximum to a minimum at the sea floor.

\section{Results}

The most conspicuous feature in the $\mathrm{Ba}_{\mathrm{d}}$ distribution is the difference between the upper $500-1000 \mathrm{~m}$ and the deep basin (Fig. 3). Concentrations below about 500-1000 m mainly range between 90 and $105 \mathrm{nmol} \mathrm{kg}^{-1}$, which appears to be the background level of $\mathrm{Ba}_{\mathrm{d}}$ of the deep Weddell-Enderby basin. At the Prime Meridian, $\mathrm{Ba}_{\mathrm{d}}$ concentrations in the deep basin ( $>1000 \mathrm{~m}$ ) appear to be highest in the central part (Fig. 3A), reaching up to $107 \mathrm{nmol} \mathrm{kg}{ }^{-1}$ between 2000 and $3000 \mathrm{~m}$ at $61.5^{\circ} \mathrm{S}$. Over the seamount Maud Rise $\left(65-66^{\circ} \mathrm{S}\right)$ and over the northernmost part of the Weddell Gyre (56$58^{\circ} \mathrm{S}$ ), deep and bottom water $\mathrm{Ba}_{\mathrm{d}}$ concentrations are the lowest. Further south, between Maud Rise and the Antarctic margin (67$68^{\circ} \mathrm{S}$ ), $\mathrm{Ba}_{\mathrm{d}}$ in the bottom layer is again slightly higher (up to $100 \mathrm{nmol} \mathrm{kg}^{-1}$ ). In the deep Weddell Sea (Fig. 3B; below $1000 \mathrm{~m}$ ) the $\mathrm{Ba}_{\mathrm{d}}$ concentration range is $84-104 \mathrm{nmol} \mathrm{kg}{ }^{-1}$, with lowest values in the northwestern part (in the vicinity of the peninsula margin) and highest in the southeastern part of the Weddell transect.

The deep waters (i.e. below $200 \mathrm{~m}$ in the central part of the Weddell section and below $600 \mathrm{~m}$ toward the western and the eastern margins of the basin) are separated from an upper layer which has concentrations $<90 \mathrm{nmol} \mathrm{kg}-1$, largely coinciding with the surface mixed layer (Fig. 3B). Since surface waters of the Weddell Gyre are eventually formed from upwelled deep water, the lower $\mathrm{Ba}_{\mathrm{d}}$ contents in surface waters must be the result of non-conservative processes which cause a partial depletion of $\mathrm{Ba}_{\mathrm{d}}$. Between $58^{\circ}$ and $65^{\circ} \mathrm{S}$ at the Prime Meridian, the $\mathrm{Ba}_{\mathrm{d}}$ isolines in the upper 500-1000 m exhibit an upward hump, typical of the divergent Weddell Gyre with westward flow in the south and eastward flow in the north, which is also seen in the distributions of other variables like $\theta$ (Fig. 2) and silicate (see below). As a consequence, the vertical extent of the $\mathrm{Ba}_{\mathrm{d}}$ depleted upper layer is zonally variable, being larger near the northern and southern boundaries of the section. North of $56^{\circ} \mathrm{S}$, i.e. outside the Weddell Gyre, the $\mathrm{Ba}_{\mathrm{d}}$ depletion zone appears to overlap with the $\theta$

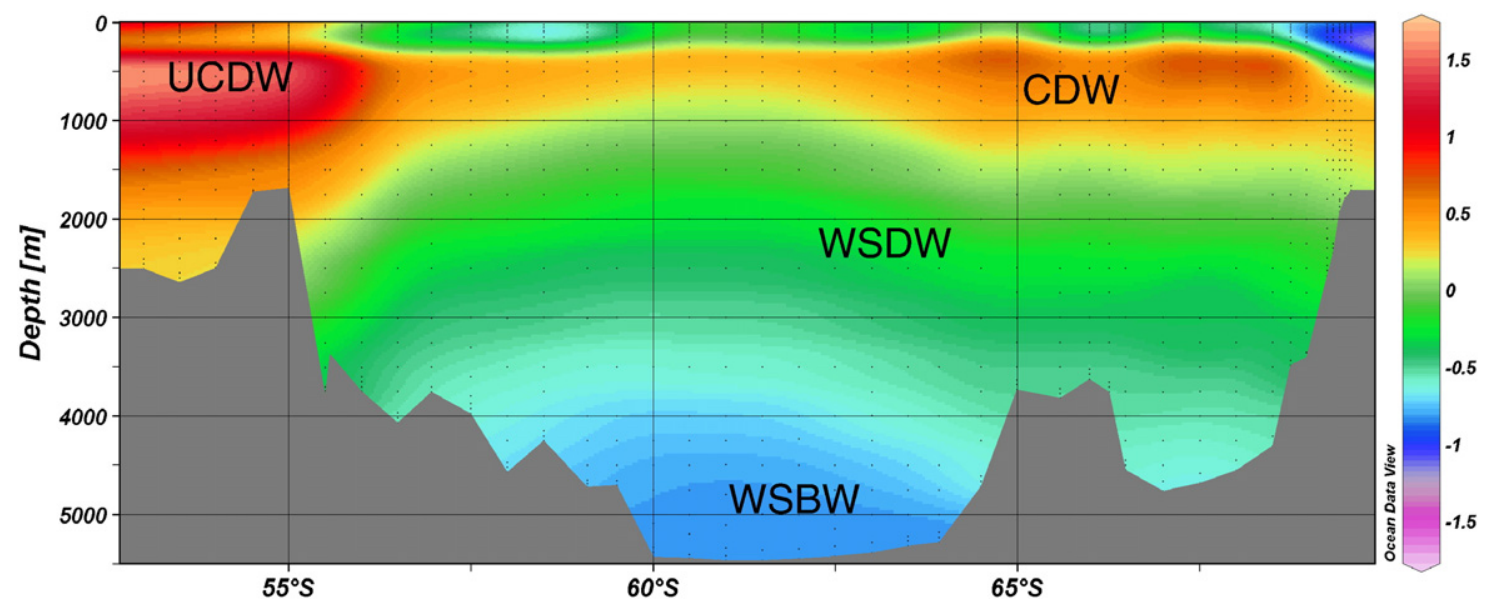

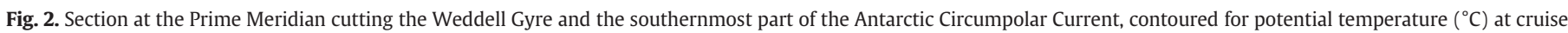
ANT-XXII/3 in 2005. 

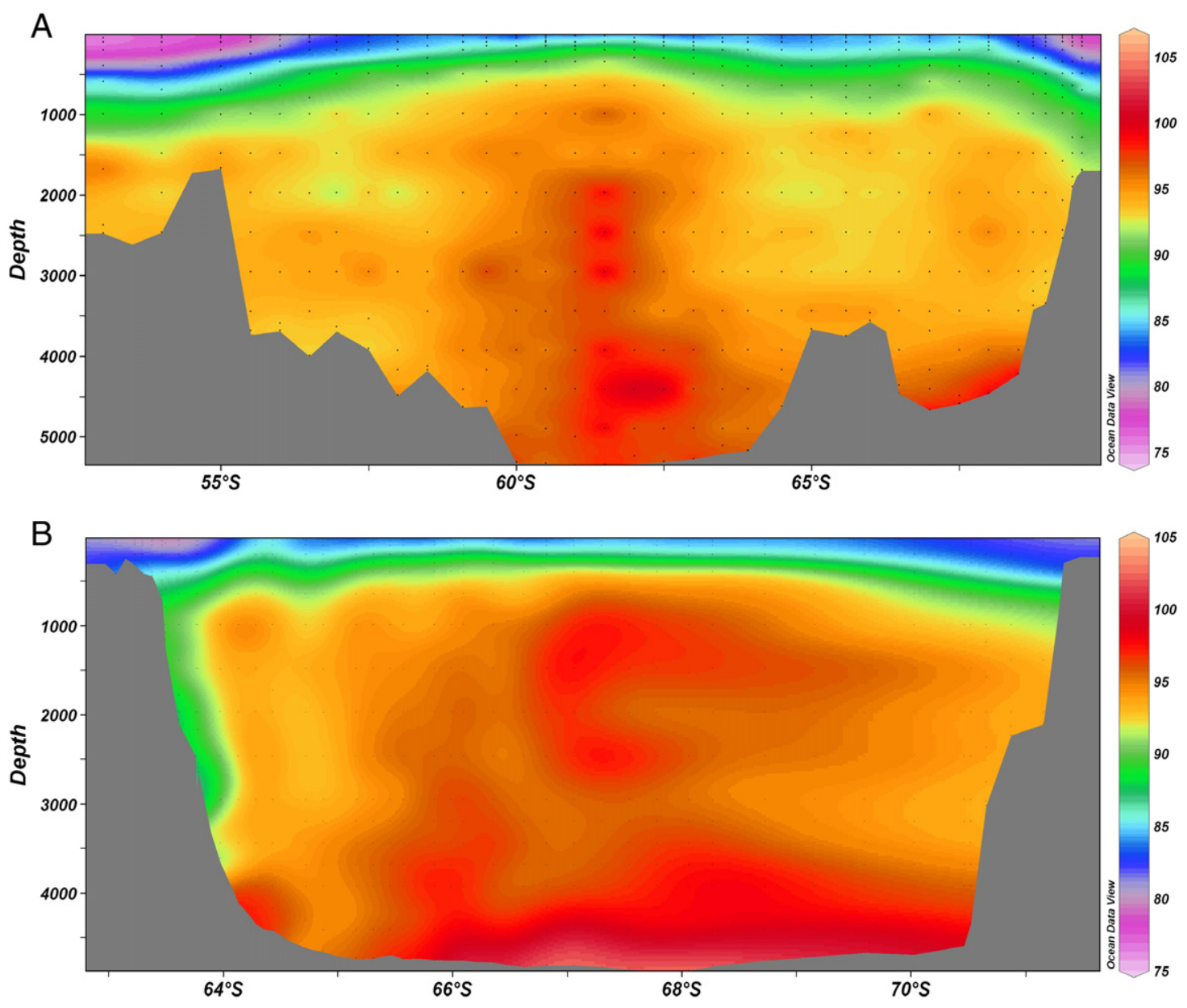

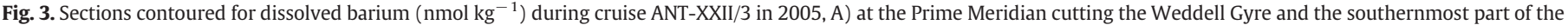
Antarctic Circumpolar Current; and B) across the Weddell Sea from Kapp Norvegia (right) to Joinville Island at the tip of the Antarctic Peninsula (left).

maximum core of the UCDW (Fig. 2). As UCDW waters were reported to contain less $\mathrm{Ba}_{\mathrm{d}}$ than the deep waters of the Antarctic Zone (Jacquet et al., 2004; Jeandel et al., 1996), this hints that the low $\mathrm{Ba}_{\mathrm{d}}$ in the upper water column of the Weddell Gyre could, at least partly, result from advection of CDW into the Weddell Basin via the westward flowing southern limb of the gyre. It should be appreciated that the front between the ACC and the Weddell Gyre at $56^{\circ} \mathrm{S}$ also constitutes a divide between the near-surface water with lower $\mathrm{Ba}_{\mathrm{d}}$ to the north and waters with higher $\mathrm{Ba}_{\mathrm{d}}$ to the south. In the coastal current at the southern end of the Prime Meridian, the mixed layer is deep because of convection, mixing and downwelling (see also $\theta$ distribution; Fig. 2), which also leads to a deeper penetration of low- $\mathrm{Ba}_{\mathrm{d}}$ waters. In addition, the $\mathrm{Ba}_{\mathrm{d}}$ concentration in the upper few hundred meters of the coastal current appears to be lower (about $77 \mathrm{nmol} \mathrm{kg}^{-1}$ ) than north of it along the section, where it reaches about $85 \mathrm{nmol} \mathrm{kg}^{-1}$. In the area between $64^{\circ} \mathrm{S}$ and $66.5^{\circ} \mathrm{S}$ the $\mathrm{Ba}_{\mathrm{d}}$ depletion reaches greater depths than north and south of it. Here, Maud Rise exerts influence on the entire water column: as circulation-topography interaction induces a Taylor column over the rise, the mixed layer extends deeper over the crest of Maud Rise than over its flanks.

Along the Weddell Sea section, the near-surface layer exhibits similar $\mathrm{Ba}_{\mathrm{d}}$ concentrations (Fig. 3B) as observed at the Prime Meridian. At both ends of the section, the low- $\mathrm{Ba}_{\mathrm{d}}$ layer also extends deeper than in the central part. At the continental shelf break of the Antarctic Peninsula, the low- $\mathrm{Ba}_{\mathrm{d}}$ surface layer is linked to a plume of $\mathrm{Ba}_{\mathrm{d}}$ depleted water hugging the continental slope down to about $4000 \mathrm{~m}$ depth. This plume consists of Weddell Sea Bottom Water, which has very recently been formed at the southern and western shelves of the Weddell Sea and which has not yet reached the bottom of the central basin (Fahrbach et al., 2001; Gordon et al., 1993). Since WSBW is a mixing product of CDW and shelf water, it carries the low$\mathrm{Ba}_{\mathrm{d}}$ properties of the latter water mass. In the WSBW at the continental slope, the shelf water component is particularly large; further along its way through the Weddell Sea, mixing with adjacent deep waters will reduce the overall contribution of the shelf water component to the WSBW, thus also increasing the $\mathrm{Ba}_{\mathrm{d}}$ concentration.

\section{Discussion}

The concentrations of $\mathrm{Ba}_{\mathrm{d}}$ are generally higher in Weddell Gyre surface waters compared to the Antarctic Zone in the Indian sector of the Southern Ocean (Jacquet et al., 2005; Jeandel et al., 1996). Such zonal variation is mainly caused by varying upwelling activity of Baenriched deep waters, although zonal differences in phytoplankton activity probably contribute as well. The latter usually is highest in the Subantarctic zone and Polar Frontal Zone to the north and decreases southwards into the Antarctic Zone, where it increases again in the vicinity of the ice edge (Jochem et al., 1995; Moore et al., 1999; Savoye et al., 2004). Our Weddell data were collected during summer, at the height of the growth season, and thus we expect the impact of biological uptake on $\mathrm{Ba}_{\mathrm{d}}$ to have been at its climax. The smaller $\mathrm{Ba}_{\mathrm{d}}$ depletions in Weddell surface waters could thus reflect lower production in the Weddell region compared to elsewhere. However, it is likely that this smaller apparent $\mathrm{Ba}_{\mathrm{d}}$ depletion is in part due to the intensity of upwelling in the divergent Weddell Gyre transferring Baenriched waters into the surface layers. Additionally, deep water that 
is being upwelled into the surface layer appears to have a higher $\mathrm{Ba}_{\mathrm{d}}$ concentration in the Weddell Gyre than in the Antarctic Zone of the Indian sector ( $c f$. Jacquet et al., 2004; Jeandel et al., 1996).

\subsection{Correlation between barium and silicate}

The distribution of $\mathrm{Ba}_{\mathrm{d}}$, both lateral and vertical, is known to show similarities with that of silicate in several ocean provinces (e.g., Chan et al., 1977; Jacquet et al., 2007a; Jeandel et al., 1996). We explore the occurrence of such a similarity for the Weddell Gyre with the corresponding silicate sections along the Prime Meridian and across the Weddell Sea (Fig. 4).

The vertical profile of silicate in the Weddell Gyre is typical for that of the major nutrients, i.e., relatively low concentrations in the surface layer, a maximum at intermediate depth, and a decrease towards the sea floor. Frequently, a silicate maximum is observed in the bottom layer (Edmond et al., 1979; Hoppema et al., 1998). Our data demonstrate a high agreement between the distributions of silicate and $\mathrm{Ba}_{\mathrm{d}}$ in the Weddell Gyre (Figs. 3 and 4). Even the lateral variation of the extent of the surface layer appears to be congruent. This condition is largely due to hydrographic processes such as upwelling and convective overturning of the surface layer.

Newly formed WSBW at the continental slope off Joinville Island can be recognized by its low silicate and $\mathrm{Ba}_{\mathrm{d}}$ concentrations (see left side of the Weddell section in Figs. 3B and $4 \mathrm{~B}$ ). It is intriguing that even the wide, but not very pronounced, silicate minimum at 3000 $3500 \mathrm{~m}$ emerging from the lower continental slope off Kapp Norvegia (see right side of the Weddell section in Figs. 3B and 4B) appears to correspond to $\mathrm{a} \mathrm{Ba}_{\mathrm{d}}$ minimum. This core of ventilated water, characterized by a CFC (chlorofluorocarbon) maximum (Hoppema et al., 2001; Meredith et al., 2000) and thus a large surface water component, originates east of the Weddell Gyre. Just like WSBW from the Weddell Sea, it is characterized by relatively low concentrations of silicate and $\mathrm{Ba}_{\mathrm{d}}$, although the signal has been attenuated during transport from the region of origin.

The deep silicate maximum (Fig. 4), which is slightly visible in plots of silicate versus salinity (Fig. 5) is caused by dissolution of biogenic silica at depth (Rutgers van der Loeff and Van Bennekom, 1989). There is no concomitant coherent $\mathrm{Ba}_{\mathrm{d}}$ maximum - the variability of $\mathrm{Ba}_{\mathrm{d}}$ in the deep Weddell Gyre appears too large although the $\mathrm{Ba}_{\mathrm{d}}$ data from the Weddell section seem to point to a weak feature (Fig. 5B). Differences between the deep distributions of silicate and $\mathrm{Ba}_{\mathrm{d}}$ should not be surprising, because the saturation state of ocean waters with respect to silica/opal and $\mathrm{BaSO}_{4}$ is different, as are the dissolution kinetics of these minerals. The water column in the Weddell Gyre is oversaturated with respect to barite in the upper $1500 \mathrm{~m}$ with barely any regional variability (Fig. 6). This indicates that no dissolution of $\mathrm{BaSO}_{4}$ should occur in the upper $1500 \mathrm{~m}$ of the water column. Based on the saturation state, no large $\mathrm{Ba}_{\mathrm{d}}$ depth gradients are expected. Silicate shows a much larger surface to depth gradient since the entire oceanic water column is undersaturated with respect to opal (Brzezinski et al., 2003; Hurd, 1972).

Regression of $\mathrm{Ba}_{\mathrm{d}}$ against silicate shows a high correlation for the combined Prime Meridian and Weddell sections $\left(r^{2}=0.81\right.$; Fig 7). The $\mathrm{Ba}_{\mathrm{d}}$-silicate regression for the Weddell region is slightly different from that for a meridional section south of the Polar Front along $30^{\circ} \mathrm{E}$ (Fig. 7: previously unpublished data by F. Dehairs and C. Jeandel of the CIVA-1 cruise 1993, WOCE I6 line). For a given silicate concentration,
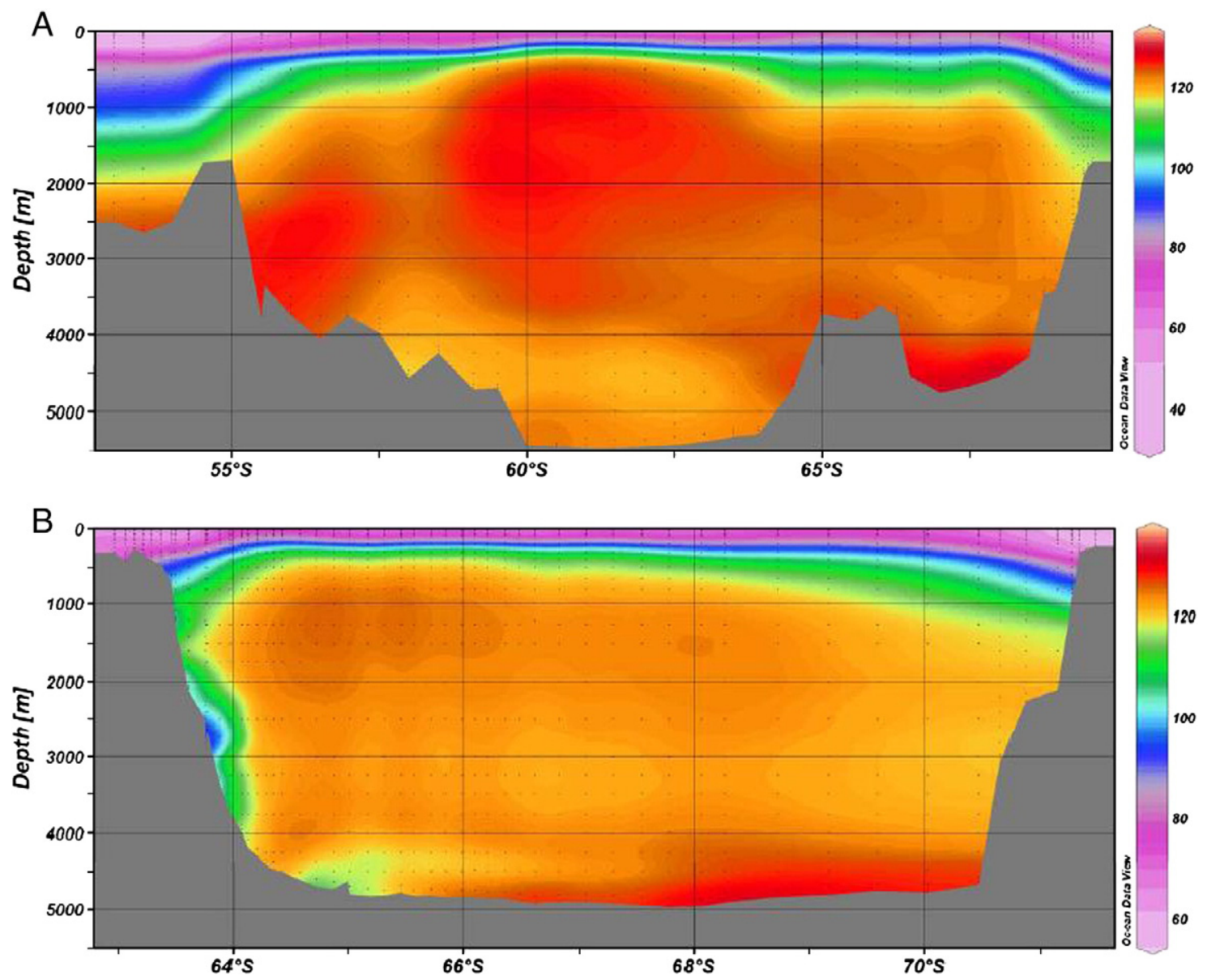

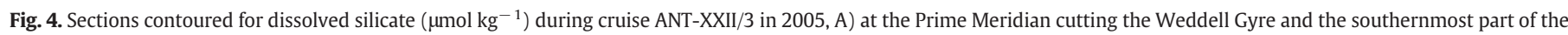
Antarctic Circumpolar Current; and B) across the Weddell Sea from Kapp Norvegia (right) to Joinville Island at the tip of the Antarctic Peninsula (left). 

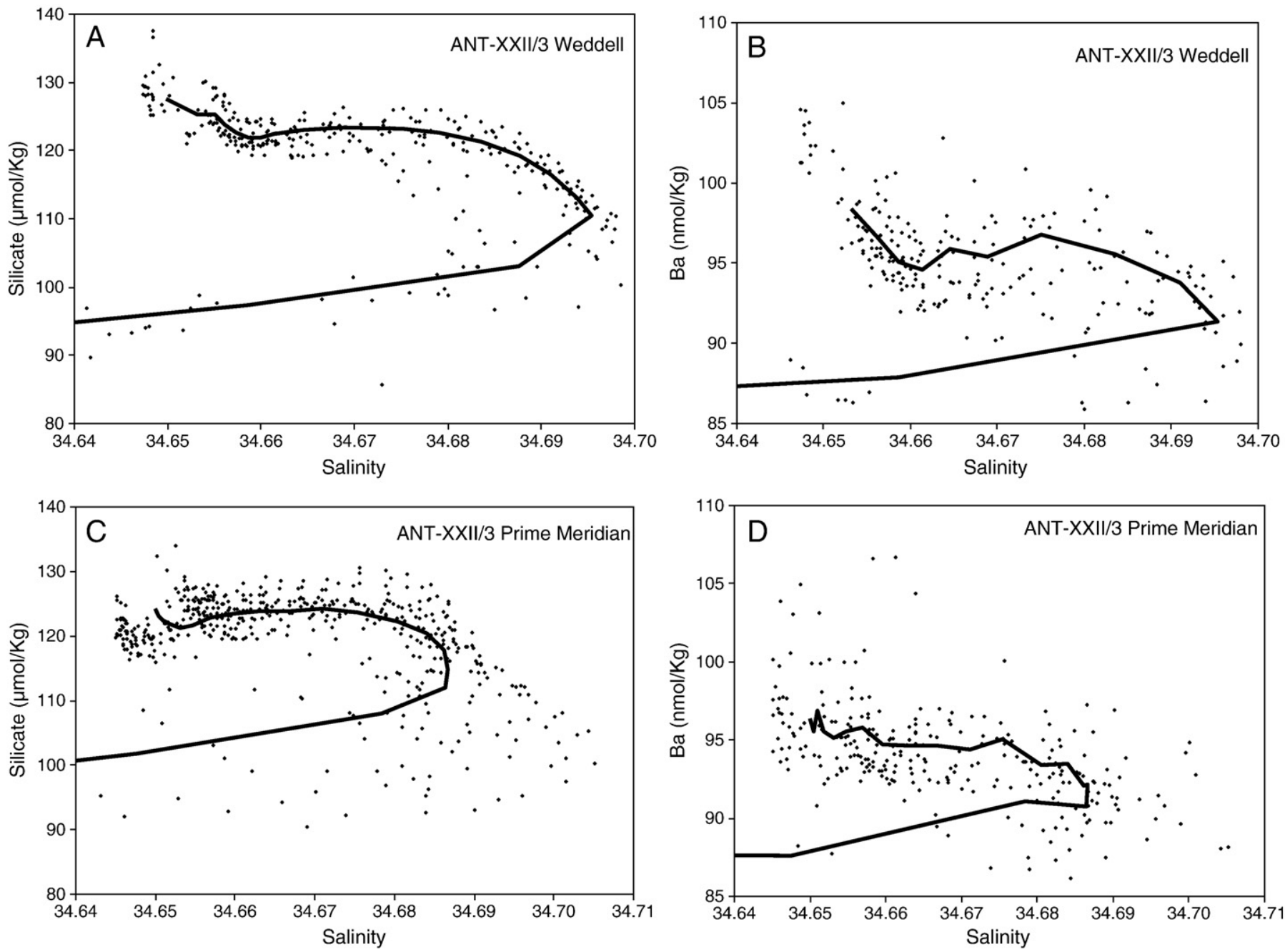

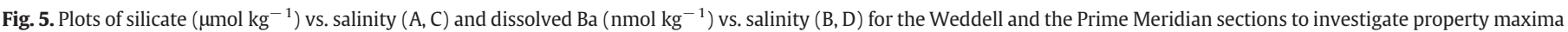
in the deep water.

the $\mathrm{Ba}_{\mathrm{d}}$ concentrations in the Weddell system exceed those at $30^{\circ} \mathrm{E}$ by about $5 \mathrm{nmol} \mathrm{kg}^{-1}$ - note that the $30^{\circ} \mathrm{E}$ section is quite near the eastern rim of the Weddell Gyre. Also, the slope of the $\mathrm{Ba}_{\mathrm{d}}$ versus silicate regression is larger at $30^{\circ} \mathrm{E}$, whereas the $\mathrm{Ba}_{\mathrm{d}}$ intercept at zero silicate is smaller (differences are significant at $p<0.005$ ). In the Weddell region, the higher $\mathrm{Ba}_{\mathrm{d}}$ level highlights the decoupling between barium and silicate and points to a mechanism for retaining $\mathrm{Ba}_{\mathrm{d}}$ within the gyre system relative to silicate. A likely mechanism is Ba translocation to particles in surface waters and Ba efflux from the sediments as discussed below. However, a smaller biological Ba to $\mathrm{Si}$ uptake ratio in the upper waters of the Weddell Sea, as compared to the ACC, could also lead to the observed differences in Ba vs. silicate regressions between both regions.

\subsection{Barium depletion in the surface layer}

Depletions of nutrients or $\mathrm{TCO}_{2}$ in the surface layer have been used frequently in the Weddell region to determine the net community production from the onset of the growth season until the time of measurement (e.g., Hoppema et al., 2007). We are using an approximate depletion here to obtain the seasonal changes of the $\mathrm{Ba}_{\mathrm{d}}$ concentration between the winter and the time of sampling. Usually, depletions are computed from the vertical integration of the concentrations above the remnant Winter Water, which is identified by its temperature minimum, and is assumed to reflect the initial prebloom conditions. Since sampling resolution in the upper layers was insufficient to warrant a reliable integration over the surface layer, we simply consider the difference in $\mathrm{Ba}_{\mathrm{d}}$ between the temperature minimum layer and the shallowest sample (at about $20 \mathrm{~m}$ ). This difference in $\mathrm{Ba}_{\mathrm{d}}$ concentrations is proportional to, and an approximate measure of, the depletion.

At the Prime Meridian, the $\mathrm{Ba}_{\mathrm{d}}$ difference between the temperature minimum and surface waters is generally in the range 0 $6 \mathrm{nmol} \mathrm{kg} \mathrm{k}^{-1}$, with an average of $3.6 \pm 3.9 \mathrm{nmol} \mathrm{kg}^{-1}$ (Fig. 8A). A slight trend of higher values towards the centre of the transect may be discerned. At the Weddell section, the $\mathrm{Ba}_{\mathrm{d}}$ difference exhibits a range of -2 to $6 \mathrm{nmol} \mathrm{kg} \mathrm{kg}^{-1}$, with few deviations to higher and lower values (Fig. 8B). The Ba difference is independent of temperature within the temperature minimum (Fig. 8C and D). At the Weddell section, the temperature minimum remains close to the freezing point of seawater of $-1.85^{\circ} \mathrm{C}$ and it therefore appears that the observed $\mathrm{Ba}_{\mathrm{d}}$ depletions are real and not affected by erosion of the temperature minimum layer.

As a bio-intermediate element, Ba becomes depleted in the surface layer with respect to the deep water underneath it (e.g., Chan et al., 1977; Jacquet et al. 2007a). Our data show that surface water Ba depletions reaching up to 8 and $12 \mathrm{nmol} \mathrm{kg}^{-1}$ (for the Prime Meridian and Weddell section, respectively; Fig. 8) are generated within a few months after the end of winter. There are several processes that may be responsible for this: first, active or passive biologically associated uptake of $\mathrm{Ba}$; and second, abiotic precipitation of $\mathrm{Ba}$ as the mineral barite $\left(\mathrm{BaSO}_{4}\right)$. As to the first cause, there are only very few phytoplankton 

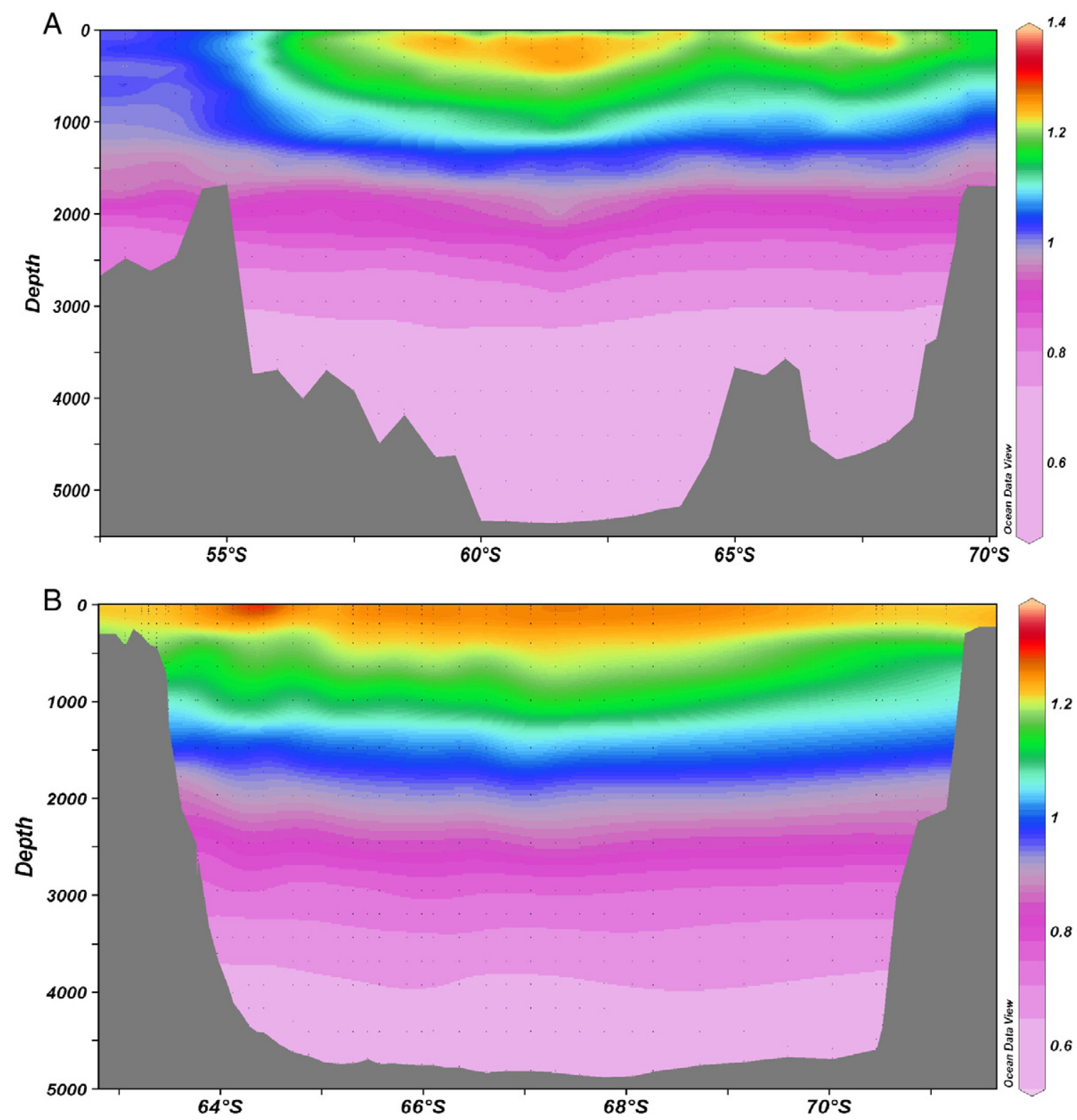

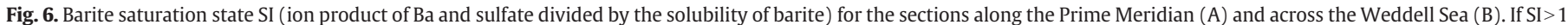
the water is supersaturated with barite.

species known to actively take up Ba (e.g., Gayral and Fresnel, 1979). However, high particulate Ba concentrations have been reported in Southern Ocean surface waters (Cardinal et al., 2005; Jacquet et al., 2007a), usually associated with elevated biomass. This Ba is generally not present as barite (Dehairs et al., 1980; Stroobants et al., 1991), but is adsorbed onto biogenic matter (diatom tests; Sternberg et al., 2005) or is incorporated into the skeletal matrix, e.g., in acantharians (Bernstein et al., 1998; Jacquet et al., 2007b). As to the second cause, our results for Weddell Gyre surface waters point to a barite supersaturation in the upper water column with a maximum saturation index of 1.4 (Fig. 6). Together with the Black Sea (Falkner et al., 1993), the Weddell Sea appears to be one of the few regions in the world's ocean where $\mathrm{BaSO}_{4}$ supersaturation prevails. Note that when barite saturation is reached, equilibrium should be the rule, as expected for salts whose kinetics of dissolution/precipitation are generally believed to be fast. Nevertheless, large $\mathrm{BaSO}_{4}$ supersaturations have also been documented for the sedimentary environment (e.g., Aloisi et al., 2004).

In the seasonally ice-covered Weddell Gyre, a third cause of depletion should be considered, namely, barite precipitation during sea-ice formation. In an already oversaturated surface ocean, salinity and solute concentrations in brine channels of the ice may reach very high values (e.g., Anderson and Jones, 1985), eventually leading to supersaturation of barite, which will result in inorganic precipitation. The large biomass of sea-ice algae, visible as green or brown ice at the base of ice floes, may further enhance Ba depletion as a result of $\mathrm{Ba}$ adsorption on algal cells and may also result in barite formation due to organic matter degradation within the sea-ice (Carson, 2008). During the EPOS-2 cruise in the Weddell Scotia Confluence in 1988, high particulate Ba concentrations were measured in brown ice (up to $8 \mathrm{nM}$ Ba, i.e., about 40 times more than the usually observed surface water particulate Ba concentrations), correlating with high POC contents (F. Dehairs, unpublished results). Carson (2008) reports dissolved Ba concentrations in sea-ice brine ranging widely from surface water values to as low as $6 \mathrm{nM}$, suggesting that significant Ba translocation from the dissolved to the particulate phase is likely in sea-ice brines. On the other hand, it must be mentioned that in laboratory experiments on freezing sea water no evidence for barite formation was found (Taylor et al., 2003; K.K. Falkner, personal communication). In the Arctic, strong depletions of Ba were found in the surface layer associated with the ice edge (Falkner et al., 1994), 


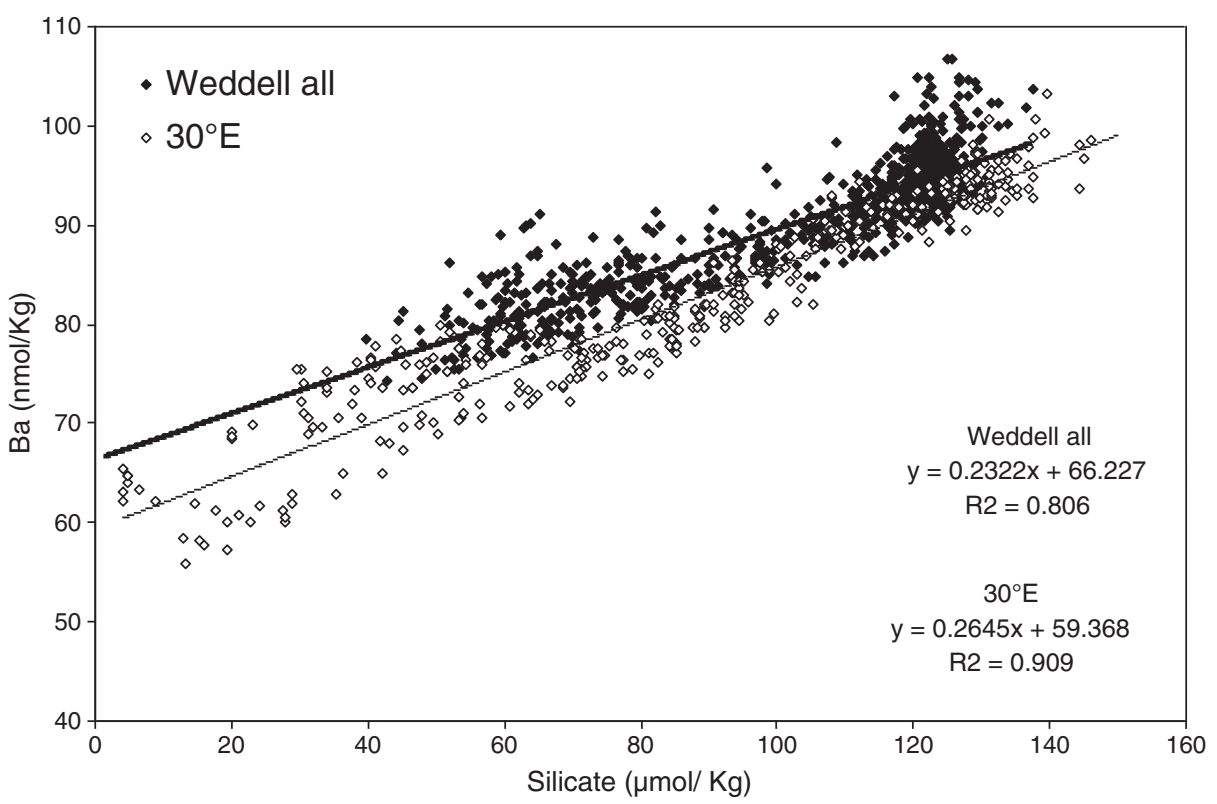

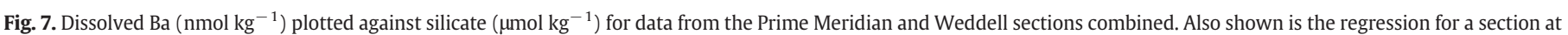
$30^{\circ} \mathrm{E}$ (1993, CIVA1 cruise, WOCE I6 line), where only stations south of the Polar Front were included.

suggesting that processes within the sea-ice play a role in $\mathrm{Ba}$ depletion; those authors hint at intensified biological activity as the main cause for this depletion. We emphasize that inorganic barite precipitation is only speculated here. However, whatever the exact mechanism, be it of biological or inorganic nature, $\mathrm{Ba}_{\mathrm{d}}$ depletion seems to be associated with sea-ice formation.

It is worth noting that barite precipitation associated with sea-ice formation occurs in autumn and winter, hence the process as such cannot explain the observed $\mathrm{Ba}_{\mathrm{d}}$ depletion of the seasonal summer mixed layer. However, barite or particulate Ba formed within the seaice will eventually be released in the surface waters, either during draining and flushing of brine waters or ultimately when the ice is melted at the end of the winter. The released barite cannot dissolve in the supersaturated surface waters but, when associated with aggregates of ice algae, it may settle to the undersaturated deep ocean where it will eventually dissolve. Overall, such a process would subtract $\mathrm{Ba}_{\mathrm{d}}$ from surface waters and redistribute it in the deep ocean. As to the seasonal depletion, the melting of sea-ice at the end of winter will dilute the upper part of the winter mixed layer more than the lower part, which also has an impact on the $\mathrm{Ba}_{\mathrm{d}}$ concentrations. Clearly, the mechanism described above would lead to variability of the $\mathrm{Ba}_{\mathrm{d}}$ depletion. Due to ice motion (which is different from the movement of the underlying water) and spatially variable rates of ice formation, the variation of $\mathrm{Ba}_{\mathrm{d}}$ depletion is further enhanced and even enrichment (i.e., negative depletion; see Fig. $8 \mathrm{~B}$ ) of $\mathrm{Ba}_{\mathrm{d}}$ is possible. We speculate that barite dissolution may even occur within the melting ice matrix.

It is interesting to note that the larger surface Ba depletion around $62^{\circ} \mathrm{S}$ on the Prime Meridian (Fig. 8A) appears to coincide with elevated $\mathrm{Ba}_{\mathrm{d}}$ concentrations in the deep basin between $2000 \mathrm{~m}$ and the bottom (Fig. 3A). This may well hint at a mechanism whereby barite is being formed in the surface layer and is subsequently transferred to the deep ocean. At greater depths where undersaturation prevails (Fig. 6), dissolution of barite causes elevated concentrations of $\mathrm{Ba}_{\mathrm{d}}$. It should be added that this mechanism is not only active in the central Weddell Gyre; it is merely most prominent there. In other parts of the basin, the $\mathrm{Ba}_{\mathrm{d}}$ concentration is to some degree determined by dissolution of barite - if the rate of surface depletion of $\mathrm{Ba}_{\mathrm{d}}$ is smaller, also less barite will be dissolved at depth. The vertical correspondence between Ba depletion in the surface and $\mathrm{Ba}$ enrichment at depth is not perfect because water currents (strength and direction) are depth-dependent. It makes sense that the correspondence is best in the central gyre, because the currents are weakest there (Fahrbach et al., 1994). It should be realized that the residence time of the deep water where $\mathrm{Ba}_{\mathrm{d}}$ enrichment occurs is many years, and thus the enrichment process occurs on an accordingly long time scale.

\subsection{Bottom layer enrichment}

Both silicate and $\mathrm{Ba}_{\mathrm{d}}$ are enriched in the bottom layer of the Weddell Sea; actually, the highest absolute concentrations of both species were observed there (Figs. 3B and 4B). For silicate, this has been previously reported by Edmond et al. (1979). Note, in contrast, that newly formed WSBW (which is the source of all bottom water in the Weddell Gyre) along the slope of the Antarctic Peninsula (Figs. 3B and $4 \mathrm{~B}$ ) is characterized by minima of silicate and $\mathrm{Ba}_{\mathrm{d}}$. This provides evidence that enrichment of bottom water occurs locally in the Weddell-Enderby basin. Even the spatial distributions of bottom layer enrichment of silicate and dissolved Ba largely conform: Strong enrichments were found along most of the Weddell section (Figs. 3B and $4 \mathrm{~B}$ ), and at the Prime Meridian especially in the southern part $\left(66.5-68.5^{\circ} \mathrm{S}\right.$; Fig. $3 \mathrm{~A}$ and $\left.4 \mathrm{~A}\right)$. In the northern part of the Prime Meridian section at $55.5-56.5^{\circ} \mathrm{S}$, a silicate maximum was observed at the bottom, but this appears to be a local deep water phenomenon, as no $\mathrm{Ba}_{\mathrm{d}}$ analogue was found at that location. Hoppema et al. (1998) have demonstrated that strong enrichment of the bottom water with silicate occurs especially in the region off Kapp Norvegia, supported by a local bottom water recirculation cell. The same process could also explain the increased bottom water $\mathrm{Ba}_{\mathrm{d}}$ concentrations in that region.

Enrichment of $\mathrm{Ba}_{\mathrm{d}}$ in the bottom layer may have two causes. First, particulate barite could rapidly dissolve at these depths because of the pressure dependence of the solubility product of barite (Monnin et al., 1999; Monnin and Cividini, 2006). The saturation index SI for $\mathrm{BaSO}_{4}$ close to the seafloor at depths $>4000 \mathrm{~m}$ drops to values $<0.6$ (Fig. 6) and enhanced dissolution of barite may only occur when SI $\ll 1$ due to kinetic effects. However, this explanation is unlikely since we found evidence for $\mathrm{Ba}_{\mathrm{d}}$ enrichment in the deep water column (see above), which hints at dissolution at depths well above the bottom layer. Second, there may be input of $\mathrm{Ba}_{\mathrm{d}}$ from the sediments to the overlying water. Biogenic barium is abundantly present in sediment cores from the Weddell Sea and environs (e.g., Ó Cofaigh and Dowdeswell, 2001). 

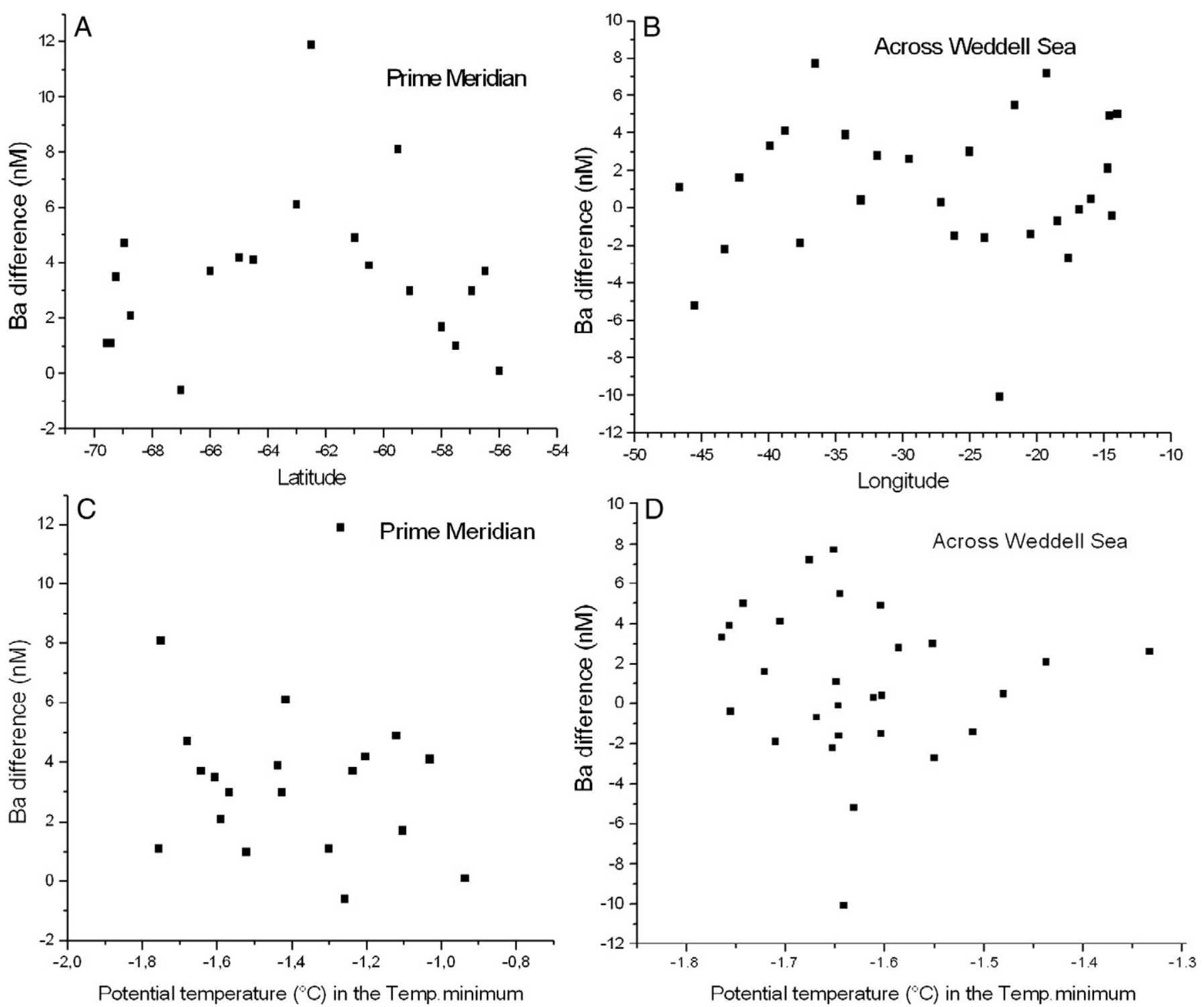

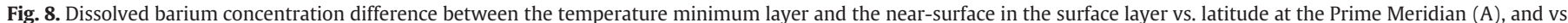

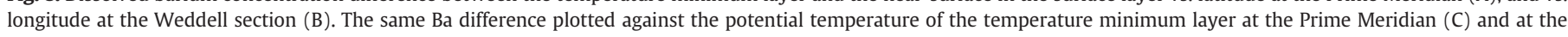
Weddell section (D).

The occurrence of enhanced vertical gradients of $\mathrm{Ba}_{\mathrm{d}}$ in the deepest samples combined with the fact that a significant epibenthic flux of dissolved Ba to the water column has been reported for other oceanic areas as well (e.g., McManus et al., 1994, 1998), suggests that efflux of Ba from the sediments contributes to elevated bottom water Ba concentrations. It is worthwhile adding that the spatial coincidence of $\mathrm{Ba}_{\mathrm{d}}$ and silicate enrichment lends high credibility to the case for $\mathrm{Ba}_{\mathrm{d}}$ input from the sediments, because opal dissolution occurs throughout the water column, and silicate efflux from the sediments has been reported in the Weddell basin (Edmond et al., 1979; Holby and Anderson, 1996; Rutgers van der Loeff and Van Bennekom, 1989).

A rough estimation of the $\mathrm{Ba}$ flux from the sediments is presented. We take the $\mathrm{Ba}_{\mathrm{d}}$ enrichment in the bottom layer to be $5 \mathrm{nmol} \mathrm{kg}{ }^{-1}$, where the vertical extent of that layer is about $500 \mathrm{~m}$ (Fig. 3B). The enrichment then amounts to $2500 \mu \mathrm{mol} \mathrm{m}{ }^{-2}$. It has been generated at the time scale of the residence time of the WSBW in the bottom layer. The residence time is tentatively calculated as 6 years, using the surface area of the Weddell Gyre where WSBW occurs (assumed to be about $1 \cdot 10^{12} \mathrm{~m}^{2}$ ), combined with the vertical extent $(500 \mathrm{~m})$ and the ventilation rate of WSBW $(2.6 \mathrm{~Sv}=$ $2.6 \cdot 10^{6} \mathrm{~m}^{3} \mathrm{~s}^{-1}$; Fahrbach et al., 1994). This yields an efflux of $\mathrm{Ba}_{\mathrm{d}}$ of about $400 \mu \mathrm{mol} \mathrm{m}{ }^{-2}$ year $^{-1}$. This value falls well within the range reported for other open ocean environments, e.g., in the Equatorial Pacific: $160-1060 \mu_{m o l ~ m}^{-2}$ year $^{-1}$ (McManus et al., 1999; Paytan and Kastner, 1996). Integrated over the Weddell Basin surface area of $1 \cdot 10^{12} \mathrm{~m}^{2}$, the $\mathrm{Ba}_{\mathrm{d}}$ efflux is $0.4 \cdot 10^{9} \mathrm{~mol} \mathrm{year}^{-1}$.

\subsection{Enrichment of dissolved barium in deep water}

Since water mass transformation and mixing take place in the Weddell-Enderby basin, the bottom water $\mathrm{Ba}_{\mathrm{d}}$ enrichment is also transferred to other water masses, in particular the voluminous deep water. We can make a rough estimation of the enrichment of $\mathrm{Ba}_{\mathrm{d}}$ in the deep Weddell basin using characteristics of the hydrography of the region. The main source of deep water to the Weddell Gyre is the inflowing CDW of the ACC near the eastern boundary. Other water masses are eventually derived from that source. At the Prime Meridian, the source water mass can be distinguished at depths of about $200-1500 \mathrm{~m}$ at $64-69^{\circ} \mathrm{S}$ (Fig. 2). Its upper boundary is the $\theta$ maximum, while the lower boundary is distinguishable as a weak maximum of both $\mathrm{TCO}_{2}$ and nutrients, occurring at $\theta$ of about $0-0.2^{\circ} \mathrm{C}$ (Hoppema et al., 1997). We compare the $\mathrm{Ba}_{\mathrm{d}}$ concentration of the 
CDW source water (marked as "inflow") with that of the remaining deep water masses at the Prime Meridian in a diagram of $\mathrm{Ba}_{\mathrm{d}}$ against $\theta$ (Fig. 9). The $\mathrm{Ba}_{\mathrm{d}}$ concentration in the inflow CDW tends to be lower than that in the rest of the basin - recall that lower $\mathrm{Ba}_{\mathrm{d}}$ concentrations were observed in the CDW of the Antarctic Circumpolar Current (see Results section and Fig. 3A). However, there is a large overlap of $\mathrm{Ba}_{\mathrm{d}}$ values for the two sub-regions. At the highest $\theta$ values, representing the core of the $\theta$ maximum, which is associated with inflowing CDW, $\mathrm{Ba}_{\mathrm{d}}$ is lowest $\left(85-94 \mathrm{nmol} \mathrm{kg}^{-1}\right.$ ). Beneath the $\theta$ maximum of the inflow water, $\mathrm{Ba}_{\mathrm{d}}$ is higher and similar to $\mathrm{Ba}_{\mathrm{d}}$ in the low $\theta$ maximum of the rest of the basin. In the deep Weddell basin with a $\theta$ range of roughly 0.2 to $-0.7^{\circ} \mathrm{C}$, the $\mathrm{Ba}_{\mathrm{d}}$ concentration is constant within about $93-101 \mathrm{nmol} \mathrm{kg}^{-1}$. Some of the highest values of $\mathrm{Ba}_{\mathrm{d}}$ are due to enrichment in the bottom layer.

Since $\mathrm{Ba}_{\mathrm{d}}$ in water of about $0.5{ }^{\circ} \mathrm{C}$ in the central and northern Weddell Gyre along the Prime Meridian coincides with that of $0.5{ }^{\circ} \mathrm{C}$ in the inflow area $\left(64-69^{\circ} \mathrm{S}\right)$ (Fig. 9), it appears that the upper portion of the inflow water with a high $\theta$ maximum $\left(>0.5^{\circ} \mathrm{C}\right)$ is upwelled into the surface layer during its traverse of the gyre. Of note is that at the Prime Meridian, we do not catch the full extent of upwelling of low$\mathrm{Ba}_{\mathrm{d}}$ subsurface water in the inflow. Part of the upwelling has already taken place in the eastern Weddell Gyre between the eastern boundary and $0^{\circ} \mathrm{E}$, changing water properties considerably (Bakker et al., 2008; Gouretski and Danilov, 1993). In the deep Weddell basin ( $\theta$ of 0.2 to $-0.7^{\circ} \mathrm{C}$ ), the $\mathrm{Ba}_{\mathrm{d}}$ concentration is higher than in the $\theta$ maximum layer, but it is largely independent of $\theta$ (with a range of about $5 \mathrm{nmol} \mathrm{kg}{ }^{-1}$; Fig. 9). Further $\mathrm{Ba}_{\mathrm{d}}$ enrichment occurs in the bottom layer (see above). This suggests that the $\mathrm{Ba}_{\mathrm{d}}$ level of the deep water is fed by input from above (surface water) and below (water with $\theta<-0.7^{\circ} \mathrm{C}$ ). Within the deep basin, mixing and uplifting of deep water takes place, which relocates dissolved Ba.

\subsection{Mass balance of Ba in the deep Weddell Gyre}

We construct a tentative mass balance of $\mathrm{Ba}_{\mathrm{d}}$ in the deep Weddell Gyre that must be consistent with the apparent enrichment of $\mathrm{Ba}_{\mathrm{d}}$ within the Gyre compared to the source waters from the ACC. Orsi et al. (1999) estimated the total Antarctic Bottom Water export of the Atlantic sector of the Southern Ocean to be about $11 \mathrm{~Sv}$. This is too high for the Weddell Gyre, because their definition of the Atlantic sector includes large regions east of the gyre. A value of 8-9 Sv may be more representative of the subsurface Weddell Gyre, as reported by Klatt et al. (2005), although also this should be considered as an upper boundary. This outflow must be balanced by an inflow of CDW and surface water from the ACC. The $\mathrm{Ba}_{\mathrm{d}}$ concentration difference between the inflowing CDW with low $\mathrm{Ba}_{\mathrm{d}}$ and outflowing deep water with high $\mathrm{Ba}_{\mathrm{d}}$ amounts to about $5 \mathrm{nmol} \mathrm{kg}{ }^{-1}$ (see Fig. 9). Taking the water export values of Klatt et al. (2005), we calculate the net Ba loss from

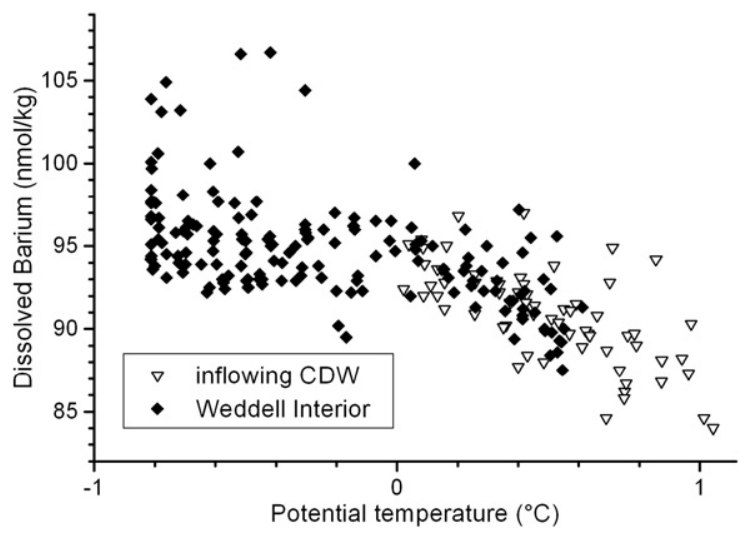

Fig. 9. Dissolved barium plotted against potential temperature. Data are from the Prime Meridian section only; surface layer data are excluded. the Weddell Gyre to the ACC to be about $40-45 \mathrm{~mol} \mathrm{~s}^{-1}$, or $1.3-$ $1.4 \cdot 10^{9}$ mol year $^{-1}$. Additionally, the deep Weddell Gyre loses water (and $\mathrm{Ba}_{\mathrm{d}}$ ) to the surface layer through upwelling and diffusion. Different estimates are being reported for the rate of vertical advection in the Weddell Sea: Hoppema et al. (2001) give a lower end range between 0.5 and $1.3 \mathrm{~Sv}$, while Weppernig et al. (1996), Mensch et al. (1996) and Haine et al. (1998) estimate vertical advection of 1.5-1.7 Sv. Taking a mean deep ocean to Winter Water $\mathrm{Ba}_{\mathrm{d}}$ difference of $15 \mathrm{nmol} \cdot \mathrm{kg}^{-1}$, vertical advection would convey $0.6-$ $0.8 \cdot 10^{9}$ mol year $^{-1}$ from the deep water to the surface. The total loss from the deep Weddell Gyre thus amounts to $1.9-2.2 \cdot 10^{9} \mathrm{~mol}$ $\mathrm{Ba}_{\mathrm{d}}$ year $^{-1}$. Assuming steady state, this figure must be identical to the supply of $\mathrm{Ba}_{\mathrm{d}}$ to the deep water. The efflux of $\mathrm{Ba}_{\mathrm{d}}$ from the Weddell Sea sediments contributes $0.4 \cdot 10^{9}$ mol year $^{-1}$ to the deep water (see above). We assume that the remaining $1.5-1.8 \cdot 10^{9} \mathrm{~mol} \mathrm{Ba}_{\mathrm{d}}$ year $^{-1}$ is contributed by supply from the surface layer (Fig. 10), where $B a_{d}$ is removed and precipitated and brought to the deep Weddell as particulate matter, where it dissolves in the undersaturated water (Fig. 6).

We computed a net loss of $\mathrm{Ba}_{\mathrm{d}}$ of the Weddell Gyre, but it should be stressed that this is only a loss from the deep gyre (Fig. 10). This excess $\mathrm{Ba}_{\mathrm{d}}$ originates predominantly from the surface layer. The surface layer of the Weddell Gyre is eventually generated through upwelling of CDW. It is apparent that the $\mathrm{Ba}_{\mathrm{d}}$ concentration in the surface layer is much lower than that of the CDW (Fig. 3), indicating that $\mathrm{Ba}_{\mathrm{d}}$ is lost from the surface layer (see also above). The Ba depleted surface water is transferred equatorwards from the Weddell Gyre through Ekman transport.

Considering a Weddell surface area of $1 \cdot 10^{12} \mathrm{~m}^{2}$, the supply to the deep Weddell $\mathrm{Ba}_{\mathrm{d}}$ reservoir, required to make up the balance, equals 4$5 \mu \mathrm{mol} \mathrm{m}{ }^{-2}$ day $^{-1}$. This is similar, but generally somewhat larger than, the Ba fluxes recorded by deep water sediment traps elsewhere. A trap at $4023 \mathrm{~m}$ from site M2 (French KERFIX/ANTARES program 1994-1995) located in the ACC beyond the eastern rim of the Weddell Gyre in the Indian sector $\left(52^{\circ} \mathrm{S}-61^{\circ} 32^{\prime} \mathrm{E}\right)$, recorded Ba fluxes between 0.2 and $2.8 \mu \mathrm{mol} \mathrm{m}{ }^{-2}$ day $^{-1}$ (average flux $=0.94 \mu \mathrm{mol} \mathrm{m}^{-2}$ day $^{-1}$; Jeandel et al., unpublished data). At the M3 site $\left(63^{\circ} \mathrm{S}-71^{\circ} \mathrm{E}\right.$; KERFIX/ANTARES program) in the seasonal ice zone further south, Ba fluxes at $1334 \mathrm{~m}$ and $3444 \mathrm{~m}$ were smaller (range: 0.06 to $0.34 \mu \mathrm{mol} \mathrm{m}^{-2}$ day $^{-1}$; average $=$ $0.14 \mu \mathrm{mol} \mathrm{m}^{-2}$ day $^{-1}$ and range 0.09 to $0.38 \mu \mathrm{mol} \mathrm{m}^{-2}$ day $^{-1}$; average $=0.22 \mu \mathrm{mol} \mathrm{m}{ }^{-2}$ day $^{-1}$, respectively; Jeandel et al., unpublished data). Sediment traps moored in the Polar Frontal Zone along $145^{\circ} \mathrm{E}$, had average Ba fluxes of 0.74 and $0.68 \mu \mathrm{mol} \mathrm{m}{ }^{-2} \mathrm{day}^{-1}$ at 800 and $1580 \mathrm{~m}$, respectively (Jacquet et al., 2007a). The particulate Ba removal estimated here is similar to the seasonal input of particulate $\mathrm{Ba}$ in the mesopelagic waters (as a result of barite precipitation in decomposing sinking aggregates) of the Polar Front along $6^{\circ} \mathrm{W}$ (1.4 $\mu \mathrm{mol} \mathrm{m}^{-2}$ day $^{-1}$; Dehairs et al., 1997), which represents at least

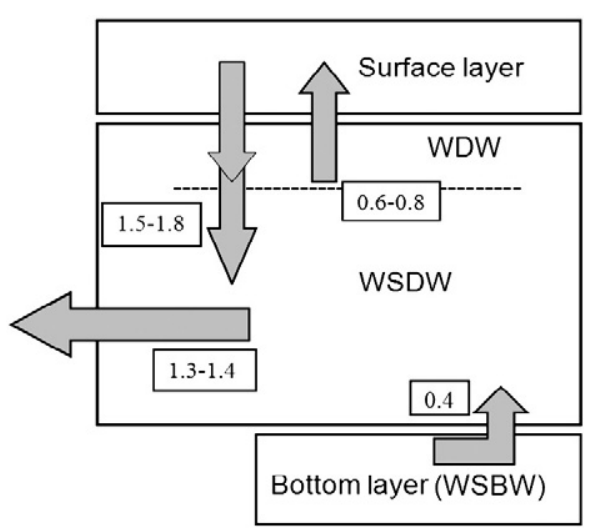

Fig. 10. Schematic representation of the deep Weddell Gyre highlighting annual fluxes of dissolved Ba (in $10^{9}$ mol year $^{-1}$ ). 
part of the vertical flux of Ba in the water column. Though it seems that the here derived apparent vertical fluxes are on the high side, we also need to consider that the total enrichment of $\mathrm{Ba}_{\mathrm{d}}$ must by nature be larger than the particulate Ba fluxes captured by deep ocean traps, because the material caught in these traps is only part of the total, the rest having been dissolved on the way. Finally, $\mathrm{Ba}_{\mathrm{d}}$ removal in the surface layer via barite precipitation associated with sea-ice formation and biological activity may be more efficient in the Weddell Gyre than in other regions because of the extensive sea-ice formation.

\section{Concluding remarks}

Two full-depth sections have provided insight into the factors determining the $\mathrm{Ba}_{\mathrm{d}}$ distribution in the Weddell Gyre. The gyre is supplied with deep water from the ACC, which is relatively low in $\mathrm{Ba}_{\mathrm{d}}$. The low $\mathrm{Ba}_{\mathrm{d}}$ concentration could still be observed at the Prime Meridian (which is some distance away from the actual ACC source). In the gyre, this low- $\mathrm{Ba}_{\mathrm{d}}$ subsurface water is upwelled into the surface layer. Further decrease of $\mathrm{Ba}_{\mathrm{d}}$ in the surface layer occurs due to $\mathrm{Ba}$ uptake as a consequence of phytoplankton activity, possibly complemented by barite formation in sea-ice. Within the voluminous deep Weddell Gyre, $\mathrm{Ba}_{\mathrm{d}}$ is enriched compared to the source water of the gyre. This is effected by barite dissolution in the undersaturated deep water (with barite originating from the depleted surface layer); and also by $\mathrm{Ba}_{\mathrm{d}}$ mixing into the deep water from the strongly $\mathrm{Ba}_{\mathrm{d}}$ enriched bottom layer. $\mathrm{Ba}_{\mathrm{d}}$ influx from the bottom layer seems to occur predominantly in the southeastern part of the Weddell basin, in exactly the same region where bottom layer enrichment of silicate occurs. Water movement and circulation further redistribute $\mathrm{Ba}_{\mathrm{d}}$ through the Weddell-Enderby basin. Tentative calculations show that enrichment of the deep water due to $\mathrm{Ba}_{\mathrm{d}}$ originating from the surface layer is likely to be larger than through $\mathrm{Ba}_{\mathrm{d}}$ supply from the bottom layer.

Summarizing, a mechanism appears to exist whereby the Weddell Gyre acts as an efficient conduit for $\mathrm{Ba}_{\mathrm{d}}$ export to the deep and abyssal world oceans. In the surface layer, $\mathrm{Ba}_{\mathrm{d}}$ is depleted due to phytoplankton activity and, possibly, barite precipitation within sea-ice. This particulate, absorbed and adsorbed Ba is subsequently exported from the surface layer by settling and redissolves in the deep Weddell Gyre. The deep water, classified as Antarctic Bottom Water, thus enriched in $\mathrm{Ba}_{\mathrm{d}}$, abandons the gyre to replenish the abyssal ocean basins to the north. $\mathrm{Ba}_{\mathrm{d}}$ depleted surface water leaves the gyre northwards through Ekman transport.

\section{Acknowledgements}

This research was supported by the Federal Belgian Science Policy Office (Belspo) under the Science for Sustainable Development (SDD) program, Brussels, Belgium (BELCANTO contract SD/CA/03A) and Vrije Universiteit Brussel (project GOA 53). We are grateful to Evaline van Weerlee (NIOZ, Texel) for the silicate measurements on board Polarstern and Rob Middag (NIOZ) for help with sampling for barium. We thank the captain and crew of Polarstern for their hospitality and help. This work was partly funded by the EU IP CARBOOCEAN (project nr. 511176, GOCE).

\section{Appendix A. Supplementary data}

Supplementary data associated with this article can be found, in the online version, at doi:10.1016/j.marchem.2010.07.005.

\section{References}

Aloisi, G., Wallmann, K., Bollwerk, S.M., Derkachev, A., Bohrmann, G., Suess, E., 2004. The effect of dissolved barium on biogeochemical processes at cold seeps. Geochim. Cosmochim. Acta 68, 1735-1748.
Anderson, L.G., Jones, E.P., 1985. Measurements of total alkalinity, calcium, and sulfate in natural sea ice. J. Geophys. Res. 90, 9194-9198.

Bakker, D.C.E., Hoppema, M., Schröder, M., Geibert, W., De Baar, H.J.W., 2008. A rapid transition from ice covered $\mathrm{CO}_{2}$-rich waters to a biologically mediated $\mathrm{CO}_{2}$ sink in the eastern Weddell Gyre. Biogeosciences 5, 1373-1386.

Bernstein, R.E., Byrne, R.H., Schijf, J., 1998. Acantharians: a missing link in the oceanic biogeochemistry of barium. Deep Sea Res. I 45, 491-505.

Bertram, M.A., Cowen, J.P., 1997. Morphological and compositional evidence for biotic precipitation of marine barite. J. Mar. Res. 55, 577-593.

Brzezinski, M.A., Jones, J.L., Bidle, K.D., Azam, F., 2003. The balance between silica production and silica dissolution in the sea: insights from Monterey Bay, California, applied to the global data set. Limnol. Oceanogr. 48, 1846-1854.

Cardinal, D., Savoye, N., Trull, T.W., André, L., Kopczynska, E.E., Dehairs, F., 2005 Variations of carbon remineralisation in the Southern Ocean illustrated by the $\mathrm{Ba}_{\mathrm{xs}}$ proxy. Deep Sea Res. I 52, 355-370.

Carson D.S. Biogeochemical controls on paleoceanographic proxies: The Antarctic sea ice environment. PhD Thesis. University of Edinburgh; 2008.

Chan, L.H., Drummond, D., Edmond, J.M., Grant, B., 1977. On the barium data from the Atlantic GEOSECS Expedition. Deep Sea Res. 24, 613-649.

Collier, R., Edmond, J., 1984. The trace element geochemistry of marine biogenic particulate matter. Prog. Oceanogr 13, 113-199.

Dehairs, F., Chesselet, R., Jedwab, J., 1980. Discrete suspended particles of barite and the barium cycle in the open ocean. Earth Planet. Sci Lett. 49, 528-550.

Dehairs, F., Goeyens, L., Stroobants, N., Bernard, P., Goyet, C., Poisson, A., Chesselet, R., 1990. On suspended barite and the oxygen minimum in the Southern Ocean. Global Biogeochem. Cycles 4, 85-102.

Dehairs, F., Shopova, D., Ober, S., Veth, C., Goeyens, L., 1997. Particulate barium stocks and oxygen consumption in the Southern Ocean mesopelagic water column during spring and early summer: relationship with export production. Deep Sea Res. II 44, 497-516.

Dehairs, F., Jacquet, S., Savoye, N., Van Mooy, B.A.S., Buesseler, K.O., Bishop, J.K.B., Lamborg, C.H., Elskens, M., Baeyens, W., Boyd, P.W., Casciotti, K.L., Monnin, C., 2008 Barium in twilight zone suspended matter as a potential proxy for particulate organic carbon remineralization: results for the North Pacific. Deep Sea Res. II 55, 1673-1683.

Dymond, J., Suess, E., Lyle, M., 1992. Barium in deep-sea sediment: a geochemical proxy for paleoproductivity. Paleoceanography 7, 163-181.

Edmond, J.M., Jacobs, S.S., Gordon, A.L., Mantyla, A.W., Weiss, R.F., 1979. Water column anomalies in dissolved silica over opaline sediments and the origin of the deep silica maximum. J. Geophys. Res. 84, 7809-7826.

Fahrbach, E. (Ed.), 2006. The Expedition ANTARKTIS-XXII/3 of the research vesse "Polarstern" in 2005. Berichte zur Polar- und Meeresforschung, 533, pp. 1-246.

Fahrbach, E., Rohardt, G., Schröder, M., Strass, V., 1994. Transport and structure of the Weddell Gyre. Ann. Geophys. 12, 840-855.

Fahrbach, E., Harms, S., Rohardt, G., Schröder, M., Woodgate, R.A., 2001. Flow of bottom water in the northwestern Weddell Sea. J. Geophys. Res. 106, 2761-2778.

Falkner, K.K., Klinkhammer, G.P., Bowers, T.S., Todd, J.F., Lewis, B.L., Landing, W.M., Edmond, J.M., 1993. The behavior of barium in anoxic marine waters. Geochim. Cosmochim. Acta 57, 537-554.

Falkner, K.K., Mac Donald, R.W. Carmack, E.C., Weingartner, T. 1994. The potential of barium as a tracer of Arctic water masses. In: Johannessen, O.M., Muench, R.D., Overland, J.E. (Eds.), The Polar Oceans and Their Role in Shaping the Global Environment: The Nansen Centennial Volume. AGU Geophys. Monograph 85, Washington DC, pp. 63-76.

Fresnel, J., Galle, P., Gayral, P., 1979. Résultats de la microanalyse des cristaux vacuaolaires chez deux Chromophytes unicellulaires marines: Exanthemachrysis gayraliae, Pavlova sp. (Prymnésiophycées, Pavlovacées). C.R. Acad. Sci. Paris 288D, 823-825.

Ganeshram, R.S., François, R., Commeau, J., Brown-Leger, S.L., 2003. An experimental investigation of barite formation in seawater. Geochim. Cosmochim. Acta 67, 2599-2605.

Gayral, P., Fresnel, J., 1979. Exanthemachrysis gayraliae lepailleur (Prymnesiophyceae, Pavlovales): ultrastructure et discussion taxinomique. Protistologica 15, 271-282.

Gordon, A.L., Huber, B.A., Hellmer, H.H., Ffield, A., 1993. Deep and bottom water of the Weddell Sea's western rim. Science 262, 95-97.

Gouretski, V.V., Danilov, A.I., 1993. Weddell Gyre: structure of the eastern boundary. Deep Sea Res. I 40, 561-582.

Haine, T.W.N., Watson, A.J., Liddicoat, M.I., Dickson, R.R., 1998. The flow of Antarctic Bottom Water to the southwest Indian Ocean estimated using CFCs. J. Geophys. Res. 103, 27637-27653.

Holby, O., Anderson, L.G., 1996. Geochemistry in an area recently uncovered from the Filchner Ice Shelf. Continental Shelf Res. 16, 1479-1488.

Hoppema, M., Fahrbach, E., Schröder, M., 1997. On the total carbon dioxide and oxygen signature of the Circumpolar Deep Water in the Weddell Gyre. Oceanol. Acta 20 783-798.

Hoppema, M., Fahrbach, E., Richter, K.-U., De Baar, H.J.W., Kattner, G., 1998. Enrichment of silicate and $\mathrm{CO}_{2}$ and circulation of the bottom water in the Weddell Sea. Deep Sea Res. I 45, 1793-1813.

Hoppema, M., Klatt, O., Roether, W., Fahrbach, E., Bulsiewicz, K., Rodehacke, C., Rohardt G., 2001. Prominent renewal of Weddell Sea Deep Water from a remote source. J. Mar. Res. 59, 257-279.

Hoppema, M., Middag, R., De Baar, H.J.W., Fahrbach, E., Van Weerlee, E.M., Thomas, H., 2007. Whole season net community production in the Weddell Sea. Polar Biol. 31, 101-111.

Hopwood, J.D., Mann, S., Gooday, A.J., 1997. The crystallography and possible origin of barium sulphate in deep sea Rhizopod protists (Xenophyophorea). J. Mar. Biol. Assoc. UK 77, 969-987. 
Hurd, D.C., 1972. Factors affecting the solution rate of biogenic opal in seawater. Earth Planet. Sci. Lett. 15, 411-417.

Jacquet SHM. Barium in the Southern Ocean: Towards an estimation of twilight zone C mineralization. Doctoral Thesis. Vrije Universiteit Brussel, 234 pp; 2007.

Jacquet, S.H.M., Dehairs, F., Rintoul, S., 2004. A high resolution transect of dissolved barium in the Southern Ocean. Geophys. Res. Lett. 31, L14301. doi:10.1029/ 2004GL020016.

Jacquet, S.H.M., Dehairs, F., Cardinal, D., Navez, J., Delille, B., 2005. Barium distribution across the Southern Ocean frontal system in the Crozet-Kerguelen Basin. Mar. Chem. 95, 142-162.

Jacquet, S.H.M., Dehairs, F., Elskens, M., Savoye, N., Cardinal, D., 2007a. Barium cycling along WOCE SR3 line in the Southern Ocean. Mar. Chem. 106, 33-45.

Jacquet, S.H.M., Henjes, J., Dehairs, F., Worobiec, A., Savoye, N., Cardinal, D., 2007b. Particulate Ba-barite and acantharians in the Southern Ocean during the European Iron Fertilization Experiment (EIFEX). J. Geophys. Res. 112, G04006. doi:10.1029/ 2006JG000394.

Jacquet, S.H.M., Dehairs, F., Savoye, N., Obernosterer, I., Christaki, U., Monnin, C., Cardinal, D., 2008. Mesopelagic organic carbon remineralization in the Kerguelen Plateau region tracked by biogenic particulate Ba. Deep Sea Res. II 55, 868-879.

Jeandel, C., Dupré, B., Lebaron, G., Monnin, C., Minster, J.-F., 1996. Longitudinal distributions of dissolved barium, silica and alkalinity in the western and southern Indian Ocean. Deep Sea Res. I 43, 1-31.

Jochem, F.J., Mathot, S., Quéguiner, B., 1995. Size-fractionated primary production in the open Southern Ocean in austral spring. Polar Biol. 15, 381-392.

Klatt, O., Fahrbach, E., Hoppema, M., Rohardt, G., 2005. The transport of the Weddel Gyre across the Prime Meridian. Deep Sea Res. II 52, 513-528.

Klinkenberg, H., Van Borm, W., Souren, F., 1996. A theoretical adaptation of the classical isotope dilution technique for practical routine analytical determinations by means of inductively coupled plasma mass spectrometry. Spectrochim. Acta B 51, 139-153.

McManus, J., Berelson, W.M., Klinkhammer, G.P., Kilgore, T.E., Hammond, D.E., 1994 Remobilization of barium in continental margin sediments. Geochim. Cosmochim. Acta 58, 4899-4907.

McManus, J., Berelson, W.M., Klinkhammer, G.P., Johnson, K.S., Coale, K.H., Anderson, R.F., Kumar, N., Burdige, D.J., Hammond, D.E., Brumsack, H.J., McCorkle, D.C., Rushdi, A., 1998. Geochemistry of barium in marine sediments: implications for its use as a paleoproxy. Geochim. Cosmochim. Acta 62, 3453-3473.

McManus, J., Berelson, W.M., Hammond, D.E., Klinkhammer, G.P., 1999. Barium cycling in the North Pacific: implications for the utility of Ba as a paleoproductivity and paleoalkalinity proxy. Paleoceanography $14,53-61$.

Mensch, M., Bayer, R., Bullister, J.L., Schlosser, P., Weiss, R.F., 1996. The distribution of tritium and CFCs in the Weddell Sea during the mid-1980 s. Prog. Oceanogr. 38, $377-415$.

Meredith, M.P., Locarnini, R.A., Van Scoy, K.A., Watson, A.J., Heywood, K.J., King, B.A., 2000. On the sources of Weddell Gyre Antarctic Bottom Water. J. Geophys. Res. 105, 1093-1104.

Monnin, C., 1994. Density calculation and concentration scale conversions for natural waters. Comput. Geosci. 20, 1435-1445.
Monnin, C., 1999. A thermodynamic model for the solubility of barite and celestite in electrolyte solutions and seawater from 0 to $200{ }^{\circ} \mathrm{C}$ and to $1 \mathrm{kbar}$. Chem. Geol. 153, 187-209.

Monnin, C., Cividini, D., 2006. The saturation state of the world's ocean with respect to (Ba, Sr)SO4 solid solutions. Geochim. Cosmochim. Acta 70, 3290-3298.

Monnin, C., Jeandel, C., Cattaldo, T., Dehairs, F., 1999. The marine barite saturation state of the world's oceans. Mar. Chem. 65, 253-261.

Moore, J.K. Abbott, M.R. Richmann, G. Smith, W.O., Cowles, J.C Coale, K.H. Gardner, W.D., Barber, R.T., 1999. SeaWiFS satellite ocean color data from the Southern Ocean. Geophys. Res. Lett. 26, 1465-1468.

Ó Cofaigh, C., Dowdeswell, J.A., 2001. Late quaternary iceberg rafting along the Antarctic Peninsula continental rise and in the Weddell and Scotia Seas. Quarternary Res. 56, 308-321.

Orsi, A.H., Nowlin Jr., W.D., Whitworth III, T., 1993. On the circulation and stratification of the Weddell Gyre. Deep Sea Res. I 40, 169-203.

Orsi, A.H., Johnson, G.C., Bullister, J.L., 1999. Circulation, mixing, and production of Antarctic Bottom Water. Prog. Oceanogr 43, 55-109.

Östlund, H.G., Craig, H., Broecker, W.S., Spencer, D., 1987. GEOSECS Atlantic, Pacific, and Indian Ocean expeditions. Shorebased Data and Graphics, Vol. 7. US Gov. Printing Off. Natl. Sci. Foundation, Washington DC.

Paytan, A., Griffith, E.M., 2007. Marine barite: recorder of variations in ocean export productivity. Deep Sea Res. II 54, 687-705.

Paytan, A., Kastner, M., 1996. Benthic Ba fluxes in the central Equatorial Pacific, implications for the oceanic Ba cycle. Earth Planet. Sci. Lett. 142, 439-450.

Rushdi, A.I., McManus, J., Collier, R.W., 2000. Marine barite and celestite saturation in seawater. Mar. Chem. 69, 19-31.

Rutgers van der Loeff, M.M., van Bennekom, A.J., 1989. Weddell Sea contributes little to silicate enrichment in Antarctic Bottom Water. Deep Sea Res. 36, 1341-1357.

Savoye, N., Dehairs, F., Elskens, M., Cardinal, D., Kopczynska, E.E., Trull, T.W., Wright, S., Baeyens, W., Griffiths, F.B., 2004. Regional variation of spring N-uptake and new production in the Southern Ocean. Geophys. Res. Lett. 31, L03301. doi:10.1029/ 2003GL018946.

Sternberg, E., Tang, D., Ho, T.-Y., Jeandel, C., Morel, F.M.M., 2005. Barium uptake and adsorption in diatoms. Geochim. Cosmochim. Acta 69, 2745-2752.

Stroobants, N., Dehairs, F., Goeyens, L., Vanderheijden, N., Van Grieken, R., 1991. Barite formation in the Southern Ocean water column. Mar. Chem. 35, 411-421.

Taylor, J.R., Falkner, K.K., Schauer, U., Meredith, M., 2003. Quantitative considerations of dissolved barium as a tracer in the Arctic Ocean. J. Geophys. Res. 108, 3374. doi:10.1029/2002JC001635.

Van Beek, P., Sternberg, E., Reys, J.-L., Souhaut, M., Robin, E., Jeandel, C., 2009. ${ }^{228}$ Ra/ ${ }^{226} \mathrm{Ra}$ and ${ }^{226} \mathrm{Ra} / \mathrm{Ba}$ ratios in the western Mediterranean Sea: Barite formation and transport in the water column. Geochim. Cosmochim. Acta 73, 4720-4737.

Webster, R.K. 1960. Mass spectrometric isotope dilution analysis. In: Smales, A.A. Wager, L.R. (Eds.), Methods in Geochemistry. Interscience, New York, pp. 202-246.

Weppernig, R., Schlosser, P., Khatiwala, S., Fairbanks, R.G., 1996. Isotope data from Ice Station Weddell: implications for deep water formation in the Weddell Sea. J. Geophys. Res. 101, 25723-25739. 